Portland State University

PDXScholar

1978

\title{
Medical social workers' attitudes toward death and related matters
}

Lon M. Stratton

Portland State University

Follow this and additional works at: https://pdxscholar.library.pdx.edu/open_access_etds

Part of the Medicine and Health Sciences Commons, and the Social Work Commons Let us know how access to this document benefits you.

Recommended Citation

Stratton, Lon M., "Medical social workers' attitudes toward death and related matters" (1978).

Dissertations and Theses. Paper 2828.

https://doi.org/10.15760/etd.2822

This Thesis is brought to you for free and open access. It has been accepted for inclusion in Dissertations and Theses by an authorized administrator of PDXScholar. Please contact us if we can make this document more accessible: pdxscholar@pdx.edu. 


\section{MEDICAL SOCIAL WORKERS' ATTITUDES TOWARD DEATH AND RELATED MATTERS}

\section{by}

Lon M. Stratton

A Practicum submitted in partial fulfillment of the requirements for the degree of

\section{MASTER OF}

SOCIAI WORK

Portland State University

1978 
TO THE OFFICE OF GRADUATE STUDIES AND RESEARCH:

The research Practicum Advisor approves the Practicum of Lon M. Stratton presented August, 1978.

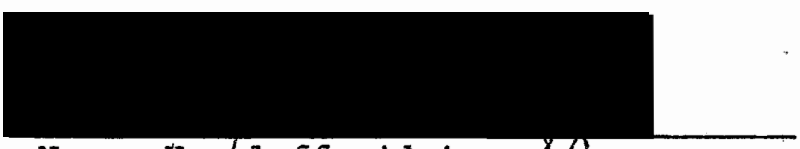
Nancy Korfloff, Advisor $0^{0}$ 


\section{ACKNOWLEDGEMENTS}

I would like to convey thanks to several individuals who have supported me during the beginning, middle and completion of this project.

(1) To my Research Advisor, Nancy Koroloff, for her time and much needed advice.

(2) To a11 of the Directors of Social Work in the major Portland hospitals for allowing me to survey their medical social work staff.

(3) To Ada Wilson for her encouragement and fine editorial guidance.

(4) To my wife and family for their understanding, patience, and emotional backing throughout this endeavor. 
TABLE OF CONTENTS

PAGE

ACKNOWLEDGEMENTS . . . . . . . . . . . . . . $i i i$

LIST OF TABLES ........................ vi

\section{CHAPTER}

I INTRODUCTION AND PURPOSE ............ 1

II REVIEW OF LITERATURE . . . . . . . . . 3

Methods Used to Collect Data Regarding

Attitudes Toward Death. . . . . . . . . 4

General Population's Attitudes Toward Death . ... 6

Attitudes of Other Medical Personnel.

Ṭoward Death. . . . . . . . . . 10

A. Physicians' Attitudes Toward Death . . . 11

B. Nurses' Attitudes Toward Death. .... 16

C. Ancillary Medical Personnel. . . . . 19

Medical Social Workers' Attitudes Toward Death. • 21

Thanatology Training in Social Work Education. . 25

III METHODOLOGY. . . . . . . . . . . 31

Pilot Study . . . . . . . . . . 32

Population Studied............ 33

Questionnaire............ 34

Data Gathering Procedure........ . 35

Analysis of Data........... 37 
RESULTS .

Demographic Data and Background Experience. : • 38

Education and Training. . . . . . . . . . 46

Specific Practice Data. . . . . . . . . . 47

Persona1 Data Related to Death and Dying . . . 50

Data Related to Specific Place of Employment. • . 54

V CONCLUSIONARY SUMMARY AND IMPLICATIONS . . • . • • . 59

Specific Conclusions. . . . . . . . . . 59

Implications. . . . . . . . . . . 62

REFERENCES CITED . . . . . . . . . . . . . . . . 65 BIBLIOGRAPHY : . . . . . . . . . . . . . . . . . . 73 APPENDICES

I PILOT STUDY QUESTIONNAIRE. . . . . . . . . . . . 78

II LETTERS SENT TO STUDY PARTICIPANTS . • . . • • • • 83

III FINAL QUESTIONNAIRE. • . . . . . . . . . . 86 


\section{LIST OF TABLES}

TABLE

PAGE

I Number of Staff and Hospitals Surveyed. . . . . . . . 39

II Social Work Positions Since Completion of MSW . • . • 40

III Years in Medical Setting Since MSW Completed. . . . . 40

IV Specialty Areas of Practice . . . . . . . . . . 41

V Other Specialty Areas of Practice . . . . . . . . 42

VI Case Loads and Terminally I11 Patients. . . . . . . 43

VII Employment Time Related to Terminally I11 Patients. • . 44

VIII Experience With Terminally Ill Patients Last Year . . . 45

IX Deaths Actually Witnessed . . . . . . . . . . 45

X MSW Adequately Prepared Social Workers for

Working With Terminally Ill Patients . . . . . . . . 46

XI Patient Should Always be Told He is Termina11y I11 . . 47

XII Responsibility for Informing Patient of Terminal

Condition . . . . . . . . . . . . . . . 48

XIII Frequent Encounter With Terminal Patients Makes

One Insensitive to Their Needs. . . . . . . . . . 50

XIV Religiosity . . . . . . . . . . . . 51

XV Belief in Life After Death . . . . . . . . . . . 51

XVI Fear of Death . . . . . . . . . . . . . 52

XVII Frequency of Personal Thoughts Toward Death . . . . 52

XVIII Terminal Illness and Wanting Doctor to Tel1 You . ... 53

XIX Future Funeral Arrangements Made By Respondents . . . 53

XX Competency of Primary Care Staff to Meet Needs

of Terminally Ill Patients and Their Families . . . . 55

XXI Social Work Department and Its offering of

Thanatology Training. . . . . . . . . . . 56

XXII Thanatology Service Improvement Needed by

Place of Employment . . . . . . . . . . . . 56

XXIII. Death and Dying Services by Social Work

Departments in Need of Improvement. 
CHAPTER ONE

INTRODUCTION AND PURPOSE

During the last ten years, a. great deal of public and professional interest has been generated in relation to the topic of death and dying. This increased attention comes at a time when society, from all visible perspective, is embracing what might be considered a life or youth oriented culture. Recently, several new books and articles have been pubIished on the topic of death and dying. The authors of this new body of knowledge have come from various professions such as medicine, nursing, psychology, social work and journalism. An example of some of the better known contributions are: Kubler-Ross' On Death and Dying $^{1}$, Kauvanaugh's Facing Death ${ }^{2}$, Langone's Vital Signs ${ }^{3}$, and Shneidman's analysis of Psychology Today's questionnaire on death. 4 In spite of the fact that death and dying is a popular subject, which attracts many authors, there continues to exist a paucity of information regarding health care workers' attitudes toward death, dying, and working. with the terminally ill patient. Social work is no exception in this area. Studies of medical social workers with respect to their attitudes about death, past and present training in thanatology, and the effectiveness of their current place of employment in dealing with the needs of the terminally ill patient, are virtually non-existent in current social work literature.

Social workers employed in hospital settings are often called to work with terminally ill patients and their families. Such social. 
work staff need to have material available for reference regarding ways in which other medical social workers have addressed the issue of personal and client death, past and present training in thanatology, and the adequacy of social work departments in meeting the needs of the terminal patient. With the current unavailability of data regarding these topics, it is important that some type of investigative effort be made to obtain this much needed information.

\section{PURPOSE OF THIS STUDY}

With the above in mind, it is the purpose of this study to examine the attitudes of several (MSW) medical social workers, currently employed in hospital settings, regarding: (1) death and dying issues, (2) education and training received related to working with the terminally ill patient, (3) specific practice issues which relate to the terminal patient, and, lastly, (4) the effectiveness of each social worker's place of employment in meeting the needs of the terminally ill patient and providing for adequate training of staff in this sensitive area. 
CHAPTER TWO

REVIEW OF THE LITERATURE

"Unlike life death cannot be taken away from man, and therefore we may consider it as the gift of God."

--Seneca

In spite of the fact that much has been recently written about death and dying, it continues to be an area of persistent concern to many individuals. Death is an experience which all biological life must eventually face. Unfortunately, human beings are not excluded from this universal maxim. Though death usually takes place in a variety of ways, each encounter, depending on the individual involved, is unique, and without duplication. Once death has permanently occurred it is irreversible. Man is not a creature who knowingly enjoys pondering his future non-existence. Perhaps it is for these reasons so many individuals have difficulty coping with their own mortality.

As previously stated, the intent of this study was to survey medical social workers' attitudes toward death and related matters. Since specific studies of this population group (medical social workers) regarding death attitudes are virtually nonexistent in medical and social work literature, it will be the intent of this researcher to present a review of material related to the following factors:

(a) general methods used to gather data regarding death attitudes,

(b) general population's attitudes toward death, (c) attititudes 
about death from other medical professionals--doctors, nurses, and ancillary staff, (d) social workers' attitudes toward death, and (e) thanatology training in social work education.

Methods Used to Collect Data Regarding Attitudes Toward Death

Research into the area of thanatology has vastly grown in the last few years. As a result of this growth, old and new methodological approaches have been used to gain perspective and enhance the understanding of data currently being collected.

Robert T. Kurlychek in a recent article entitled, "Assessment of Attitudes Toward Death and Dying--A Critical Review of Some Available. Methods," has described what he considers to be five methods which can and have been used to collect death related attitudinal data. 5 These different approaches were: the questionnaire, the interview, projective techniques, physiological measures, and death rating scales.

From Kurlychek's perspective, the questionnaire has been frequently used to collect data regarding death attitudes longer than any other method known. He cited questionnaire studies conducted in $1896^{6}$, $1936^{7}$, and $1970^{8}$ to illustrate this point. In this article, interview methods were discussed in terms of their applicability for geriätric and child respondents. 9, 10, 11 Projective techniques (Thematic Apperception Test) were also noted; however, emphasis was placed on the fact that they are not currently being utilized to gather data in this area because of their difficulty in scoring, administration, and lack of impressive results regarding reliability and validity. 12,13 The use of physiological measures (Galvanic 
Skin Responses) as an indicator of death attitudes was presented next; however, it was noted there is serious contention that the GSR is only a measure of autonomic arousal and not an interpretation of a positive or negative attitude toward a given stimulus. 14,15 According to Kurlychek, the most frequent method now being used to assess death attitudes are the death attitude rating scales. These have proliferated with great abundance in the last few years, and are now routinely being used to gather this type of data. 16 Referring to such scales, Dickstein in his article, "Attitude Toward Death, Anxiety, and Social Desirability," has stated "the recent manifestation of these numerous scales is illustrative of the emerging interest relative to attitudes toward death." 17 The scales which have created the most interest are the Death Concern Scale, ${ }^{18}$ the Tolor/Reznikoff Death Anxiety Scale, ${ }^{19}$ the Templar Death Anxiety Scale, ${ }^{20}$, and the Fear of Death Anxiety Scale. 21

In comparing the above four scales for reliability, Dickstein has noted all four share what could be considered a modern commonality, they are correlated with measures of general anxiety and manifest a significant social desirability component. ${ }^{22}$ In spite of these comparisons, Dickstein has suggested that research is needed to assess the validity of the various scales, and to explore the relationships between death attitudes and other significant dimensions of personality. 23

In summary, Kurlychek noted five methods used to collect data regarding attitudes toward death and dying. of those five, only two are currently being used with any frequency. They are the questionnaire 
and death attitude scales. Regarding these scales Dickstein has indicated that in spite of their popularity further research needs to be done to find out how valid such scales are in determining death attitudes. $^{25}$

\section{General Population Attitudes Toward Death}

Death has, for some time, been a taboo subject which generates a considerable amount of distaste within the mainstream of today's society. ${ }^{26}$ In spite of this fact, conscious and rational people still occasionally contemplate their feelings or attitudes regarding death. These feelings, no doubt, range from terror 27 to active acceptance. 28

There are several factors in today's society which have propelled members of the general population further and further away from facing and understanding death. ${ }^{29}$ Some of these are as follows: (a) the present family structure now rarely includes parents or grandparents, (b) elderly family members are now isolated in apartments or nursing homes where they are usually left by themselves, 30 (c) youth is greatly emphasized today, age is devalued and the cognizance of the total life process, birth-life-death, is completely ignored, (d) advancement in general health services and health services technology has removed dying from the home and the family to the hospital and strangers, 31 (e) morticians have turned burial rights into elaborate occasions which suggest the message that death has not really taken place, 32 (f) many religious officials strengthen the denial of death by focusing on the hereafter to the exclusion of helping the living with problems surrounding bereavement : 33 
In assessing specific attitudes toward death which are held by the general population, one should consider such factors as cultural backgrounds, childhood experiences, religious beliefs, education, types of employment, and personal encounters with dying individuals. Also, to be considered are the various types of studies used to collect this data. Investigations in this area range from Shneidman's examination of 30,000 responses to the Psychology Today questionnaire on death to Joseph Zinker's intensive analysis of a single individual's attitudes toward death. 35

Few studies really attempt to measure the general population's attitudes from a complete demographic perspective. Much of the literature currently in print focuses on specific population groups such as the elderly, the dying, the young, or identified employment populations like doctors, nurses, etc. Consequently, large studies, including all sectors of society with respect to death attitudes, are almost nonexistent.

The specific literature which will be reviewed in this section addresses the general adult population. Three studies have been chosen to illustrate the general population's attitudes toward death. These studies are being used for two reasons: (a) they illustrate the denial and acceptance approach to death prevalent in our society today, and (b) they contain sizable populations thus increasing the potential for widespread representation.

The first study to be presented is Schneidman's examination of 30,000 respondents to the 1970 Psychology Today Death Questionnaire. 36 This questionnaire contained seventy-five items which explored 
childhood experiences related to death, demographic information, beliefs about after life, and questions regarding wills, suicide, and death rituals.

The majority of those who responded was female (63\%) under the age of fifty. Thirty-nine per cent of the population was married. Fifty-three per cent was single, and nine percent was widowed. The average income was between $\$ 10,000$ and $\$ 15,000$, with thirty-eight per cent of the population having attended some college. Percentages related to major religious backgrounds were : Protestant 50\%, Catholic $30 \%$, and $11 \%$ Jewish.

As far as specific attitudes toward death, $22 \%$, or approximately one-fifth of those in the study, stated they thought of their own death on a frequent basis. Fifty-seven per cent implied they considered this topic occasionally (more than once a month). Nineteen per cent said they felt fearful when thinking of their own death, five per cent said they became discouraged at such a consideration, and eleven per cent responded that this topic made them feèl depressed. .

of those sampled, $66 \%$ said they would want to die in old age and $29 \%$ indicated just after the prime of life. Sixty-nine per cent said they felt they would die in old age and nineteen per cent thought they would probably die just after the prime of life. With respect to death preference, $38 \%$ preferred a sudden but not violent death, $30 \%$ indicated they wanted a quiet dignified death, and $1 \%$ (300 individuals) said they wanted a tragic or violent death. 
As far as sacrificing their life, $58 \%$ of the participants said they would do such a thing for a loved one, $15 \%$ indicated they would for a moral principle, $11 \%$ remarked they. would in a grave emergency to save someone's life, and $16 \%$ said they would not sacrifice their life for any reason. Also, of those surveyed $60 \%$ replied they had at one time thought of suicide, however, $40 \%$ had never known such thoughts. The next study to be reviewed is Daniel Cappon's examination of 14,000 individuals at the Montreal World's Fair in 1967. 37 This study consisted of surveying participants regarding their attitudes toward a number of direct and indirect conclusions about death. The population examined was $50 \%$ male and $50 \%$ female. Fortyseven per cent of those surveyed was under the age of 29 , the rest was over 30 . One-third of the respondents was Catholic, 1/3. was Protestant and $12 \%$ was Jewish. Regarding education, $44 \%$ had university or college degrees, $36 \%$ had gone to technical college or high school, and $20 \%$ was dropouts; $30 \%$ came from cities with populations between 100,000 and $1,000,000$.

In this study, a majority of the participants responded they had no wish to die. Yet more than one-fifth of those surveyed stated they have thoughts of their own death more than once a month. Of those included in the study, a majority believed in euthanasia, and a small amount did not believe in life after death.

Lastly, a study by Riley gives evidence of what is noted as the general population's acceptance of death. ${ }^{38}$ This is in contrast to the two previous studies which suggest death denial attitudes on the part of those surveyed. The population of this third study was made up of 1500 adults from the U.S.A. 
of those surveyed, only $4 \%$ indicated they feared or possessed an emotional anxiety related to death. It was further assessed that education more than age was a crucial variable in determining attitudes toward death. People with limited educational attainment, no matter their age, were more likely to agree with negative propositions regarding death.

Other results which were extracted from this survey suggest that a great majority of all the respondents at all age levels agreed with the propositions that "death is sometimes a blessing," and death is not tragic for the person who dies, only for the survivors." 39

In summary, the conclusions of these studies do vary; however, they illustrate what E. Mansell Pattersen calls the death denial-death acceptance dialectic. 40 of the three studies; Shneidman's appears to display the widest demographic differential because of its comprehensive size. It should be noted that until more comprehensive studies involving large populations are conducted, a lack of understanding will continue to exist with respect to general population's attitude toward death.

Attitudes of Other Medical Personnel Toward Death

Social workers employed in present day medical settings frequently encounter various health care professionals. Ideally, the social worker is just one of several providers of care that make up the "health care team." Since information regarding social workers' attitudes toward death and related matters is for the most part nonexistent or at 
least unpublished, it is imperative that some review of the literature be given which encompasses those professions with which medical social workers interface. Such a review will provide perspective regarding other medical care providers' attitudes toward death. It will also open up to scrutiny some of the rigid stances which have been taken by the medical community regarding death and the handling of this subject.

\section{A. Physicians' Attitudes Toward Death}

Death and the study of medicine are antithetical to each other; likewise are the doctor and his attitudes toward death. By virtue of the type of practice most physicians are engaged in, it is inevitable that they will come in contact with death on a somewhat frequent bașis. For this reason, some research has been conducted to try and assess physicians' attitudes toward death. Of the data collected, only a few studies can be considered definitive with respect to their compiled results. The reason for this stems from what researchers call non-cooperation. 41,42

It can easily be inferred from looking at the research literature that doctors either refuse to cooperate or display a poor response rate when it comes to answering questions related to death. Perhaps the most salient examples are as follows. In a study conducted by Caldwell and Mishara, 73 physicians were approached and initially agreed to participate in the study. When they found the research was related to death and dying, $82 \%$ of the sample refused to cooperate leaving a response rate of 13 or $17 \%{ }^{43}$ Another study which illustrates a poor response on the part of doctors was conducted by Peretz, et al., 
571 doctors were contacted regarding their attitudes toward death; $85 \%$ of the population refused to be involved in the study. 44,45 Lastly, this type of response rate is further shown in a study conducted by Travis, et al. where $50 \%$ of the physicians sampled did not reply to the study. $46,: 47$

Schulz and Aderman in their article, "How Medical Staff Copes With Dying Patients--A Critical Review," identify two major reasons for physicians' non-compliance, or avoidance behavior related to this subject area. 48 These are the physician's personality, and the physician's medical training. In refèrence to the doctor's personality, many researchers feel the reason the doctor pursues such a vocation as medicine is because of his inordinate fear of death. 49 . Becomming a physician then can be interpreted as an attempt to master death. 50 Kasper, also agrees with this point, and adds, "part of the psychological motivation : of: the physician is to cure himself and live forever. The doctor wishes to be a scientist in order to gain mastery over 1ife." 51,52

More specific evidence for this postulative position is found in an article by Livingston, and Zimet in which these investigators reasoned that medical students high in authoritarianism would be better defended against unconscious fears and therefore would have less overt death anxiety. As a result, these students would function comfortably in specialities where death is relatively common. Students low in authoritarianism, on the other hand, would be aware of and made uncomfortable by their death anxiety, and as a result would choose specialities where death is an uncommon event. 53,54 The result of the above authors' investigation supported this hypothesis. 
With respect to medical training, there is a general paucity of preparation in helping the medical student to deal with death and dying issues. 55 Most doctors are instructed to be empathetic and involved with their patients, but to remain objective. 56 This sometimes gets translated into what is known as "detached concern." 57 Medical training centers on the saving or the prolonging of life. As a result, giving much attention to death and terminal patients can sometimes be associated with failure and disappointment on the. part of the doctor. A patient's death challenges the physician's ability as a healer, and sensitizes him to the temporal limits of his own life. 58

Repression of death in medical training is not something which occurs only in American medical schools. Erwin Ringle, a European physician in the German psychiatric journal entitled, Dynamische Psychiatrie, states the repression of death and dying puts medicine in a paradoxical situation; its objective is to struggle against death and to remove it from its practice. In the struggle with the physical aspect of the patient, emphasis is placed on the conservation of life, thus dying must be denied since it creates a feeling of failure and results in the doctor leaving the patient alone. 59

In addition to the several studies cited here as examples of physicians' non-compliance with researchers regarding there attitudes toward death two individual studies will. be presented in which the response rate of the physicians sampled exceeded ninty-two per cent. The first study was conducted by M. P. Rea, et al. ${ }^{60,61}$ The total study population was 174 , and 163 (94\%) of those involved returned their questionnaires. 
As a result of this study, it was found that of the doctors sampled, many exhibited a great deal of concern and anxiety regarding terminality and dealing with this topic. It was also noted that older doctors may be more uncomfortable in working with the terminal patient than their younger colleagues. In reference to informing the patient of a terminal condition, the responses grouped in what could be called an unequal bi-modal pattern, with the physicians preferring either telling or not telling. No compromises or alternatives to these two categories were suggested or indicated. The majority of the physicians sampled were in favor of telling patient's about the seriousness of their condition as well as rejecting extreme measures to maintain life.

The second study to be included here was conducted by L. Stratton and M. Hammon. ${ }^{62}$ In this effort the researchers randomly sampled 28 physicians out of a total population of 70 from a major hospital care facility located in Portland, Oregon. Twenty-six of those involved in the sample sent back their questionnaires resulting in a return rate of $93 \%$. The physicians sampled came from speciality areas such as pediatrics, internal medicine, neurosurgery, and general surgery. The doctors surveyed were very cooperative. One hundred per cent felt it was the physician's responsibility to inform the patient of a terminal condition. Seventy-seven per cent did not want to know the exact date of their death, yet $82 \%$ indicated they would like to be told by their physicians if they had a limited time to live. Last1y, $27 \%$ of those sampled thought of their own death once a week, $36 \%$ once a month, $18 \%$ once a year, $9 \%$ never and $9 \%$ gave no response. 
In nearly all the studies reviewed by this researcher, the most discussed matter was whether to tell or not tell the patient he or she is dying. Statistics show that between $69 \%$ and $90 \%$ of physicians depending upon the study favor a conspiracy of silence regarding their terminal patients. ${ }^{63}$ Yet, $77-89 \%$ of patients surveyed, depending on the study, state they want to know the truth about their illness. 64, 65, 66 In addition to the above statistics, several articles have been written advising the physician of the general public's feelings regarding this matter, $67,68,69$ however, only a few researchers have actually attempted. to determine the extent to which such advice has been followed. $70,71,72$

Noyes points out the doctor holds the key to providing the patient with a good death. This is done by the physician informing the patient of his condition. 73,74 Such a posture is also taken by Kubler-Ross, who stresses the importance of the doctor in meeting the needs of the dying patient. She states, "through intimate interaction, the physician can help the patient reach a calm acceptance of his death." 75, 76 Other authors who agree with this position are Glasser and Strauss in their book, Awareness of Dying. 77 It is also worth note that several practitioners who deal with cancer patients recommend that it is best to be truthful and gentle with the patient. $78,79,80$

Further investigation into this area of advising the patient about his impending death has been conducted by oken. 81,82 In his study which addressed this issue, 219 doctors were selected for sampling, and only 95 responded. Part of the intent of Oken's research effort was to find out where the doctors secured their 
policy of not telling the patient he or she was dying. The results showed that $5 \%$ of the doctors acquired it in medical school or hospital training and $77 \%$ adopted it through clinical experience. Also, in this study it was revealed that a great portion of the doctors sampled felt that any major policy change with respect to telling patients of their terminal condition was unlikely. Lastly, another statistic which came out of this investigation was that $10 \%$ of those who responded stated they felt that research should not be conducted in this area. ${ }^{83}$ This noted objection is similar to responses received by Israeli physicians in a study reported by $D$. Schreibaum in the Israel Annals of Psychiatry and Related Disciplines. ${ }^{84}$

Summarizing this area, it can be said that doctors' attitudes toward death reflect more of a denial than acceptance perspective. Studies reported in much of the literature illustrate this through physicians' non-compliance in research efforts. It can be further generalized that in spite of physicians like Kubler-Ross, the majority of doctors today prefer death to be a subject about which nothing is discussed and very little is said.

B. Nurses' Attitudes Toward Death.

The volume of literature regarding nurses ${ }^{i}$ attitudes toward death and related matters is very small. As with physicians, this has not been an area frequently researched. Perhaps the most appropriate way to begin this section is with the following anecdote:

Once upon a time a patient died and went to heaven, but was not certain where he was. Puzzled, he asked the nurse nearby: "Nurse, am I dead?" She replied: "Have you asked your doctor?" 
It is a sad commentary, but this story is in many respects a truthful presentation of the current role the nurse plays in dealing with the terminal patient. Within the hospital setting, it is the nurse, more than any other group, who must deal intimately with dying patients. 86 However, the nurse most frequently is accorded a secondary role and allowed to exercise her help only within the confines of what might be considered a M.D.iety sanction. This unfortunately gets translated into the unwritten policy of "don't let the dying patient know what is happening to him," 87 or ask your doctor.

After examining the literature related to this topic, the most comprehensive study found to date was a survey completed by Nursing Magazine in 1975. 88 In this study, 15,430 nurses responded to a death and dying questionnaire located in the November, 1974, issue of Nursing Magazine. Of those who sent in questionnaires, the majority indicated they have to deal with dying patients at least two or three times a month. The nurses who seldom contact dying patients appeared to be able to deal with the fear of death just as well as those who encountered dying patients on a more frequent basis.

Regardless of how much contact the nurses had with dying patients, one-half stated they had come to grips with their death, one-third partially so, and one-eighth not at all.

When dealing with terminal patients, $62 \%$ said such a task was more demanding than working with other seriously ill individuals. Twenty-six per cent of the survey responded they avoid terminal patients, $28 \%$ said they go out of their way to give dying patients 
extra care, and $45 \%$ indicated they treat terminal patients the same as any other patient. Also in this study, $60 \%$ said the dying should be told of his condition as soon as possible, $21 \%$ stated "only if the patient asks," $16 \%$ indicated over a period of time, and $2 \%$ said never. The majority of the current literature bears out the fact that nurses, as well as doctors, approach death from a denial perspective. Many nurses feel the dying patient should be left alone to die in peace. $89,90,91$ The inability of nurses to deal with the dying patient is sometimes related to the fact that nurses are "recovery oriented." When the chances for recovery pass and it is obvious the patient is going to die, death is seen as a failure of the health care team--nurses included. 92

In analyzing the nurses' training which induces death avoidance behavior, Quint, in her book The Nurse and the Dying Patient, states, "it was found that the very young nurse is made to feel very concerned about making mistakes. She learns to defend by concentrating on routines and rituals which tend to alienate her from the patient she is caring for." 93 Thus, it can be suggested that avoidance of terminal patients may be internally justified by having duties which must be attended to whether they be important or not.

Other inferences which can be made from the available data regarding nurses' attitudes toward death are: (a) fear of death is not dependent or positively related to the practice speciality chosen by the nurse; 94,95 and (b) the key to positively modifying nurses' attitudes toward death is through nursing education and clinical experience. 96, 97 
In sumary, nursing education does not generally prepare nurses to work with dying patients. As recently as 5 to 7 years ago, many nursing curriculi limited their consideration to post-mortem care only. 98 Involvement with the patient. and the family was not considered appropriate. As a result of such lack in thanatology training, many nurses approach the topic of death with avoidance and denial. In order to ameliorate this current situation, nursing programs need to integrate recovery care with terminal care so to emphasize the positive aspects of working with the dying patient. In programs where this has been done, nurses' attitudes toward death and dying have improved considerably. 99

\section{Ancillary Medical Personnel}

Research regarding death attitudes of ancillary medical personnel is very small. Three articles were located which attempt to identify attitudes toward death by such a population.

In the first article, "Attitudes of Physical Therapists Toward Death and Terminal Illness," 100 the authors present the results of a questionnaire that was administered to 115 physical therapists regarding this topic. The results of the study indicated no significant correlations could be made between attitudes toward death, demographic data, place of current employment, types of patients treated by the participants, or the number of terminally ill patients seen by the health care providers.

Questions from the instrument were compared with other studies of nurses 101 and readers of Psychology Today. ${ }^{102}$ Al1 groups were 
similar in their basic attitudes toward death. In comparing physical therapists with nurses, the physical therapists had a greater tendency to believe in influences of psychological factors on the dying patient, and' were less willing to advocate all possible efforts in preserving life. In the second article, "Death Attitudes and Experiences of Rehabilitation Counselors," 54 rehabilitation counselors were surveyed. 103 The majority of the respondents indicated they felt their personal beliefs could potentially influence service to disabled individuals, particularly in the area of terminal illness and suicide. of this population, $46 \%$ was female and $54 \%$ was male. Eighty-nine per cent had at least some graduate training and $48 \%$ had masters degrees. Sixtyseven per cent reported thinking about their own death occasionally while $26 \%$ stated they did not have such thoughts, or if they did it was rare. Regarding terminal illness, $65 \%$ of the respondents wanted to be told if they were going to die.

The last study to be reviewed in this section is entitled. "Attitudes Toward Death Among Nursing Home Personnel." 104 In this presentation, staff such as nurses aides, LPNs and some RNs were sampled. Since a sizable portion of the population was not RNs and formed a rather distinct population group, this study was placed in this section as opposed to the nursing group previously noted.

This article presents a survey of 68 nursing home staff regarding their attitudes toward death. Among those surveyed were nurses aides, LPNs, RNs, and some nursing students. The purpose of 
this study was to investigate differences in attitudes among personnel towards the death of patients based on levels of skill, nursing experience, personal experience with death and religious differences.

Significant relationships were obtained comparing levels of skill and nursing experience with the dying patient. Those individuals having more experience with death displayed a greater uneasiness than untrained personnel when discussing this topic with terminally ill patients. Lastly, it was noted by the authors that since this was the first rigorous study conducted in nursing homes on attitudes toward death, the conclusions of necessity must remain tentative.

\section{Medical Social Workers' Attitudes Toward Death}

Perhaps the the most salient fact regarding medical social workers' attitudes toward death is the current.lack of published material addressing this topic. In reviewing all issues of the two major health oriented social work journals, Health and Social Work and Social-Work in Health Care, no studies specifically related to measuring medical social workers' attitudes toward death and dying. were found. A second investigation of a11 copies back to 1956 of the two most important practice journals, Social Work and Social Casework, revealed the same informational deficit. Considering a great number of social workers are employed in private and federal medical settings it would seem that research into this area is greatly needed.

In spite of the fact that currently no specific literature exists regarding medical social workers attitudes toward death, a few articles have been written about social workers and death from 
a practice perspective. Such efforts have been designed to help social workers develop skills needed for working with the terminally ill patients and their families.

From the beginning, social work writings in this area have suggested the dying patient should not be avoided. Admonitions for social work as a profession to not turn its back on this type of client were not uncommon. 105 Such support for working with the terminal patient has continued till the present, even though evidence exists which suggests that social work at times has embraced somewhat of a denial approach regarding this subject area. 106

Much of the current theoretical basis for social work involvement related to this topic has been generated by Lindemann, 107 Parad, ${ }^{108}$ and Caplan. ${ }^{109}$ These individuals' theories compose a body of knowledge defined as crisis theory. Crisis theory and crisis intervention are now frequently used by social workers when working with terminally ill patients and their families.

Goldberg, in his article, "Family Task and Reactions in the Crisis of Death," identifies two characteristics of death which make it a crisis situation. One is its stark finality, or the irretrievable loss of a human being, the other is the lack of coping patterns and experience one usually has in dealing with such an event. 110 Goldberg's position is that death creates personal and familial grief which must be resolved. Since death is such an anxiety laden event, it is important that proper grief work be facilitated to prevent what might be considered a maladaptive mourning reaction. This can be accomplished through good social casework which emphasizes 
the allowing of mourning, relinquishing the memory of the deceased, and realignment of intra-and extra-familial roles. 111

Another piece of literature in this area which relies on crisis theory for some of its theoretical base, is Eda Goldstein's "Social Casework and the Dying Person."112 In this article, the author identifies several aspects of crisis theory and ego psychology which are used as an essential basis for developing skills in working with the terminal patient. Some of these are: crisis resolution is not seen merely as curative, or preventive, but as ego enhancing; every crisis has identifiable tasks; and every successful crisis resolution calls forth and strengthens the ego's adaptive capacity. ${ }^{113}$ In essence, all crises throughout the life cycle allow for ego mastery. Thus, instead of viewing death as a crisis necessitating an emotional decathexis from 1ife, it can be seen as a developmental phase involving participation by the ego of the individual and the positive involvement of the family. 114

Simos, in her article, "Grief Therapy to Facilitate Healthy Restitution," states that death and its resultant grief is a time of crisis. ${ }^{115}$ She also agrees with Lindemann ${ }^{116}$ and others that grief must be shared at some time with another person in order to reestablish ties to another individual. ${ }^{117}$ For a time the therapist serves as a replacement for the lost object. ${ }^{118}$ In acute and severe situations, frequent individual sessions may be needed at the onset; however, these can be tapered off as the pain of grief lessens and the person begins to feel more comfortable. 119 
Two recent sources of salient information regarding social work and death are: (a) Leon Ginsberg's first chapter of the book entitled, Social Work With the Dying Patient and the Family, ${ }^{120}$ and, 121 Carl Pilsecker's article in Social Work, called "Help for the Dying." Both of these contributions have been written within the last three years and reflect current thinking in this area.

Ginsberg begins his chapter by stating that death is an enemy of all medically related professions, medical social work included. He further notes that death does not fit the current modes for treating social problems. Such methods and related social work theory center around strategies of elimination or amelioration and do not apply in this area. ${ }^{122}$ Death is one problem which cannot be banished. As an alternative, Ginsberg suggests that social workers who work with terminally ill patients can be effective in the following ways: (a) helping the patient accept his/her death, (b) serving the needs of those patients who face lingering deaths, and (c) providing counseling which enables people to plan intelligently for the balance of their lives, and for the lives of those around them such as family members. ${ }^{123}$ Also, in this article Ginsberg alludes to the aforementioned lack of information currently available in this area, and how research and programs oriented toward social work and thanatology are presently needed.

Pilsecker's article also illustrates ways that social workers can effectively work with terminal patients. It is Pilsecker's opinion that the dying process generates need which can be directly met through social work skills and techniques. Most importantly 
Pilsecker states if social workers are to reach out to the terminally ill patient they must offer more than just good will. ${ }^{124}$ Pilsecker offers five categories of help which the social worker can provide the terminal patient. They are: planning for living during the terminal process, exploration of feelings about impending death, living with the prospect of death, planning for death, and planning for the family after death. 125

In summary, medical social workers' attitudes toward death are currently not very well documented. Present social work literature emphasizes a practice oriented approach with little or no research being done regarding the actual providers of social work services to the terminally ill. Referring to the practice literature now in print, most of it is based on an ego psychology and crisis theory orientation. Recent contributions in this area center around learning how to offer one's self to help the patient resolve his or her impending death openly, without euphemism, and without the denial of reality. 126

Thanatology Training in Social Work Education

One of the factors addressed by this practicum was medical social workers' attitudes toward graduate education, and its effectiver ness in preparing them to work with the terminally ill patient and his family. At present there are no specific studies available in the annals of social work literature which address this topic. Social work education in the past has centered around the examination of human conditions which have resulted in the separation of family members by physical and emotional illness, economic crisis, 
social dislocation, and child abuse or abandonment. ${ }^{127}$ Course work related to death and dying has been slow to develop in most schools of social work. ${ }^{128}$ A collective examination of schools of social work curricula will quickly confirm this observation. 129 Considering that thanatology training in schools of social work is still a recent and infrequent addition to the curriculum, it is not surprising that only a small amount of information related to the training of social workers in this area is available. The majority of this material is contained in two sources: a new book Social Work With the Dying Patient and the Family, ${ }^{130}$ and an article in the Journal of Education for Social Work, entitled "Preparing Students for Effective Social Work Practice Related to Death."131 The book Social Work With the Dying Patient and the Family, contains three chapters written by three different authors which address the issue of training the graduate social work student in the area of death and dying. The titles and authors of these chapters are: (a) "Teaching a Social Work Perspective on the Dying Patient and His Family," by Eda Goldstein, ${ }^{132}$ (b) "Helping the Social Work Student Deal With Death and Dying," by Helen Cassidy, ${ }^{133}$ and (c) "Teaching Death and. Dying Content in the Social Work Curriculum," by Rosalind Miller. ${ }^{134}$

Ms. Goldstein begins her chapter by identifying the stereotypical denial and avoidance which develops among personnel working in health care settings. She further describes the current value system of society which emphasizes youth, productivity, the future, and reinforces the lack of resources and care available for the dying. 
Goldstein defines what she considers to be three essential elements for teaching a social work perspective of the dying patient. These are values, knowledge, and skills. 135

With reference to values this author 1ists several theoretical positions which have contributed to current thought related to death and dying--Freudian, crisis theory, and ego psychology. It is her value position that death should not be viewed as an end but rather as a time which can be facilitative of growth either in a personal and/or familial way. Her contention is that death can neither be completely denied or avoided and to embrace a deathdenial attitude is just reflecting repressive cultural values which need to be changed.

The second part of Ms. Goldstein's approach is the imparting of knowledge about dying patients, their families, and the ways medical services and social work manpower can be used to meet human needs. Such a venue results in death being defined as a phase of the life cycle, or if you will."...a biopsychosocial stage having tasks for the dying person, his family and the social environment."136 Lastly, the third segment of her teaching approach addresses the skill component in working with dying patients and their families. Goldstein sees this as a facilitative process which embodies the assessing of client needs, resources and intervening in such a way as to accomplish the best desired results. 137

Helen Cassidy in her chapter, "Helping the Social Work Student Deal With Death and Dying," places emphasis on helping the student resolve any conflict he may personally have regarding death. It 
should be noted this was also stressed in all of the other chapters as well as in the article being reviewed in this section. Cassidy states:

....to engage in a productive helping process with patients and their families amid the grief, sorrow, and crisis aspects attendent on the death, the student must become aware of his own reactions, know his own feelings, and be willing to plunge into self-scrutiny as a preface. to the development of insight.

Part of Cassidy's approach to her students was twofold:

(a) helping them to learn the role of the professional helper in life-death crises, and (b) integrating the experience of working with death through preparation of the student. These were accomplished by having the student repeatedly make contact with terminal clients so they would develop skills in assessing these individuals' strengths and weaknesses, and their capacity to meet crisis. ${ }^{139}$ Also used were sessions in which specific cases or feelings were discussed to bring about the resolution of any difficulty or conflict related to working with the terminal patient.

Of the three chapters noted above, Rosalind Miller's contribution was the most formal and theoretical. She began her chapter by talking about death and dying courses as a recent addition to social work curriculum. Next she spent time illustrating what she calls the Teacher/Student Transaction--that being the difficult task of the graduate school teacher to transfer his own mastered skills of. dealing with death and dying to the young graduate student who lacks experience and knowledge in this topic area. 140

Miller then described her approach to introducing death and dying content into the classroom. This was done by helping the student reach for his own feelings regarding death. Lastly, Miller 
dealt with the subject of teaching death and dying content from a rather theoretical perspective! In this approach, she cited readings which can be used with students and taltked about: family systems, homeostatic balance, response to crisis, role reversals, and awareness of family roles as they applied to death and dying: 141

Lister and Cochuros in their article, "Preparing Students for Effective Social Work Related to Death," noted that effective practice in the area of death and dying requires not only knowledge of the problems associated with dying but also skill and sufficient comfort to extend appropriate help. Since this article specifically described a practice module sequence ${ }^{142}$ being taught at the University of Hawaii, School of Social Work, its focus was specifically on the training of graduate student population.

The authors began their discussion by listing several assumptions which guided the development of the course content and class process. The first set of assumptions concerned society's view of death, and the second dealt with the needs and responses of students. As a result of these assumptions, two course objectives were identified. They were: (a) to open up a potentially charged area for discussion based on information supplied through various media, selective community experiences, and self-examination of attitudes; (b) to prepare students to be responsive and helpful as they work with individuals: threatened with death, and to be receptive when they encounter. clients who are grieving over the death of someone close to them. ${ }^{143}$ In order to assess the benefits of the course described in this article, a before and after questionnaire was used to gather information 
about perceived competence and comfort in various situations involving problems with death and dying. Comparison of responses on these "before and after questionnaires" indicated a greater comfort and feeling of competence on the part of the respondents after taking the course. Fivethere restiens. of the questionnaires also showed that about one-half of the students took the course in order to become personally comfortable with the subject matter; while the other half was more interested in learning about the subject and acquiring technical competence. ${ }^{144}$

Also stressed was the importance of the social worker's ability to evaluate the client's emotional, environmental and physical situation. In all of these articles, emphas is was placed on the student and not the training of inadequately prepared staff currently working with terminally ill patients. All of the listed authors felt that their approaches were successful, however only in the last article was this assumption supported by what could be considered appropriate data. Lastly, all of the articles contained extensive and relevant bibliographies which would be helpful to the student trying to increase his knowledge in this area. 
CHAPTER THREE

\section{METHODOLOGY}

The study which is being reported in these pages centers around medical social workers' (MSW) attitudes regarding death and related matters. In order to gather data which addresses this area of investigation, nine basic research questions were compiled. These questions were used as a guide for the study, and the development of the questionnaire. It is to these questions that this study is directed.

The basic research questions which were examined are as follows:

(1) How many (MSW) medical social workers are currently employed in the eleven major Portland hospitals?

(2) How many of the medical social workers surveyed work with terminally ill patients?

(a) What per cent of these MSW's caseloads consists of terminal patients?

(b) What per cent of these MSW's time is spent working with terminally ill patients and their families?

(3) Do the medical social workers. who were surveyed have any training related to dealing with terminally ill patients and their families?

(4) How do the medical social workers surveyed feel about the adequacy of their graduate training. in preparing them for working with the terminally ill patient and their family? 
(5) How do the medical social workers surveyed feel about issues related to their own death?

(6) Do the medical social workers surveyed feel their place of employment provides adequate services for terminally ill patients and their families?

(a) Hospital in general?

(b) Social Work Department specifically?

(7) What do the medical social workers surveyed feel is the most important thing they can offer a terminally ill patient?

(8) What do the medical social workers surveyed feel are the essential skills needed to deal with the terminally ill patient and his/her family.

(9) How do the medical social workers surveyed feel about the training offered by their place of employment as it relates to working with the terminally ill patient and his/her family?

(a) Hospital in general?

(b) Social Work Department specifically?

\section{Pilot Study}

During February, 1977, a preliminary questionnaire was pre-tested at the Veterans Hospital in Vancouver, Washington. This questionnaire was given to seven of the (MSW) medical social workers employed at that hospital. It was generally felt by all of the pilot participants that the questionnaire was adequate, and addressed the subject matter appropriately.

In spite of the agreement regarding the adequacy of the questionnaire, several comments were made as suggestions for refining some of the parts of the data collection instrument. The most prevalent statement made regarding the questionnaire was that the questions were placed too close together and needed to be given some space to make 
them appear less confined on the page. Some of the other suggestions made were: the questionnaire needed to be organized into specific sections with headings identifying each area being sampled, and the questionnaire contained too many extensive fill-in questions resulting in too much time being needed to complete the questionnaire.

As a result of the suggestions received on the pilot survey, several changes were made to the original questionnaire. The number of essay or fill-in questions was reduced from nine to three. One question was completely removed from the questionnaire because it did not extract any usable information. Four questions were expanded to allow for more itemized responses, and six questions were entirely altered so they could be answered in a multiple choice manner. The questionnaire was divided into five specific sections each focusing on a different area of interest. Lastly, the order of some of the questions was changed so to bring about a better sequential flow of items in each of the various sections. A copy of the pilot questionnaire can be found in Appendix $I$.

\section{$\underline{\text { Population Studied }}$}

The population used in this study consisted of all the (MSW) medical social workers employed in Portland's eleven major hospitals during the month of March, 1977. This resulted in fifty-eight social workers being surveyed. Out of the fifty-eight social workers included in the study, fifty-six returned their questionnaires. of the social workers sampled, all were involved in some type of practice specialization. These specializations included: pediatrics, psychiatry, general medicine, oncology, surgery, geriatrics, general medicine and administration. 
The criteria used to define the hospitals which were selected consisted of four factors. (1) The hospital had to have fifty or more beds. (2) The hospital must have an emergency room. (3) The hospital must employ at least one (MSW) medical social worker. (4) The hospital must not be designated as a mental health facility.

\section{Questionnaire}

The questionnaire used to acquire data for this study was five pages in length. It contained thirty-three questions and was divided into five individual sections. These sections were as follows: (1) demographic data and background experience related to the practice area of death and dying, (2) educational and training data related to working with the terminally ill patient and his/her family, (3) specific practice information which applies to working with terminally ill patients and their families, (4) personal data regarding social workers' attitudes toward death and dying, (5) information related to present place of employment (i.e., training available for staff in thanatology. and the type of care given to the terminally ill patient by the hospital and social work staff).

The final data collection instrument sent out to all of the participants of this study contained several types of questions. The first type of question used was simple multiple choice, ranging from "Do you have any fear of dying?" to "What per cent of your caseload is made up of terminally ill patients?" The second kind of question employed in the collection of data for this study was a multiple choice question which used a Lickert response scale. 
This allowed the respondent to place his or her answer on a five point scale ranging from being in agreement to disagreement with a pre-identified statement.

The third type of question used in the questionnaire followed a simple completion format. These questions asked for very specific answers such as age, sex, and the number of months the participants had been working in specific areas of medical social work. The last kind of inquiry administered via the collection instrument was a brief essay question. This required the respondent to give some detail in answering the question.

A copy of the final questionnaire has been placed in Appendix III.

\section{Data Gathering Procedures}

In order to obtain the endorsement to conduct this study, individual contact was made with all of the persons in charge of the social work departments surveyed. During each meeting the basic format of the study was outlined, and examples of the type of questions which might be used were presented. Confidentiality was guaranteed to all of the respondents, and it was igreed no statements comparing one hospital with another would be used. With the exception of naming the hospitals whose social work departments participated in the study, no other identifying information was to be made available regarding the respondents and their place of employment. All of the directors of social work contacted gave their complete authorization to survey the MSW staff of their departments.

The questionnaire used in this study was sent out during the week of March 22, 1977. Some of the questionnaires were hand delivered, 
others were sent by mail. Attached to each questionnaire was a stamped return addressed envelope, along with a letter of introduction stating the purpose of the study and how the results were going to be used. Also included in the letter was a date by which the questionnaire needed to be returned.

In order to determine which questionnaires had been returned, a two digit code identifying each social worker and his/her place of employment was placed on each of the questionnaires. A key for the different codes was made and used in deciphering which questionnaires had been returned. When a questionnaire was returned the code was checked on the key making it possible to rapidly calculate the total number of questionnaires returned.

One week after all of the questionnaires had been sent out 45 , or $77.5 \%$, of the questionnaires were returned, Two weeks after the start of the survey 50 , or $86 \%$, of the questionnaires had been sent back. At this point a letter of reminder was sent to all of those individuals who had not returned their questionnaires. Attached to the letter was a stamped return addressed envelope. By the end of the third week 53 , or $91 \%$, of the questionnaires were returned. During the fourth week three more questionnaires were received. After the fourth week no more questionnaires were sent in. Follow-up was made regarding the two respondents who did not return their questionnaires. Both questionnaires had been sent to individuals who currently were unavailable at their place of employment because of vacation or illness. The final return rate for the study was 56 questionnaires, or $96.5 \%$ of the total population surveyed. 
Analysis of Data

After the fifty-six responses were received, and it was ascertained that no more would be returned, all of the answers on each of the questionnaires were coded, key punched, and tabulated using Portland State University's computer. Each question was analysed in terms of frequency count, per cent of response.for individual categories contained in each question, mean scores, and 'standard deviations. For the essay questions which required an open-ended response, the answers were individually identified and manually counted, thus resulting in an itemized tabulation of the answers most commonly given. 


\section{CHAPTER FOUR}

\section{RESULTS}

The purpose of this study was to investigate all of the MSW medical social workers employed in the eleven major Portland hospitals, regarding their attitudes toward death and working with the terminally ill patients and their families. It should be noted that this research was not designed to prove or disprove any preconceived hypotheses. Considering that no published studies exist to date concerning this topic, it was this researcher's intent to develop an exploratory questionnaire which would survey and collect relevant data regarding this much neglected field of inquiry. The findings which were made as a result of the study are as follows.

Demographic Data and Background Experience Related to Death and Dying As previously stated, this study consisted of fifty-six respondents from eleven Portland hospitals. The response rate was $96.5 \%$. The names of the hospitals surveyed and the number of staff which participated from each hospital are listed in the: following Table I. 
TABLE I

NUMBERS OF STAFF AND HOSPITALS SURVEYED

\begin{tabular}{lcc}
\hline Hospital & Frequency & Per Cent \\
\hline Veterans Hospital & 13 & $22.4 \%$ \\
University of Oregon Medical School & 10 & 17.2 \\
Good Samaritan Hospital & 10 & 17.2 \\
Providence Hospital & 7 & 12.5 \\
Kaiser Hospital & 5 & 8.6 \\
St. Vincents Hospital & 4 & 6.8 \\
Emanuel Hospital & 4 & 6.8 \\
Seventh Day Adventist Hospital & 2 & 3.4 \\
Physicians and Surgeons Hospital & 1 & 1.7 \\
Woodland Park Hospital & 100.0 \\
Medical Center Hospital & 1 & 1.7 \\
\hline Total & 1 & 1.7 \\
\hline
\end{tabular}

* Note only 56 were returned.

of the fifty-six individuals who sent in their questionnaires $16(29 \%)$ were male and $40(71 \%)$ were female. The average age of the participants was 38.8 or in rounded numerals 39 . The range of ages for those who responded was from 25-65. The standard deviation for the age category was 9.9. 
The number of medical social worker positions held by the participants since they completed their MSW is listed in Table II.

TABLE II

SOCIAL WORK POSITIONS SINCE COMPLETING MSW

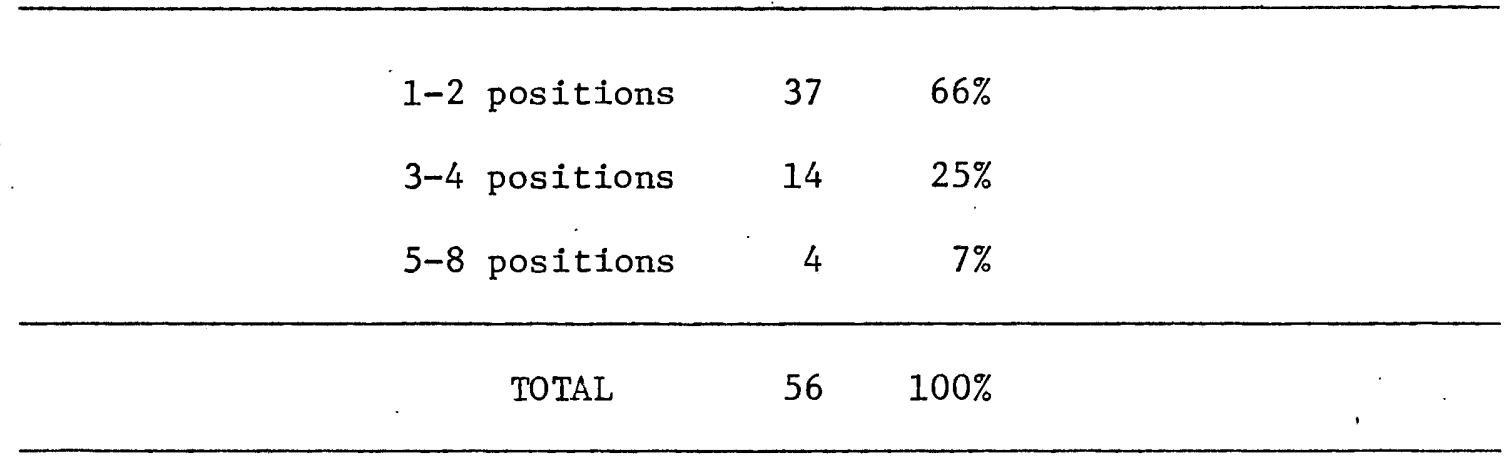

The next question asked related to the number of years each respondent had practiced in a medical setting since the completion of the MSW. The results are in table III.

TABLE III

YEARS IN MEDICAL SETTING SINCE MSW COMPLETION

$\begin{array}{lrr}\text { Less than one year } & 6 & 11 \% \\ 1-4 \text { years } & 29 & 52 \% \\ 5-8 \text { years } & 12 & 21 \% \\ 9-12 \text { years } & 4 & 7 \% \\ \text { More than } 12 \text { years } & 5 & 9 \%\end{array}$

TOTAL

$56 \quad 100 \%$


As part of the information gathered in this section it was requested that the social workers identify any specific areas of practice which they have worked in. Table IV gives a. Iist of the different categories of practice and what per cent of the survey had been exposed or not exposed to each area.

TABLE IV

SPECIAITY AREAS OF PRACTICE

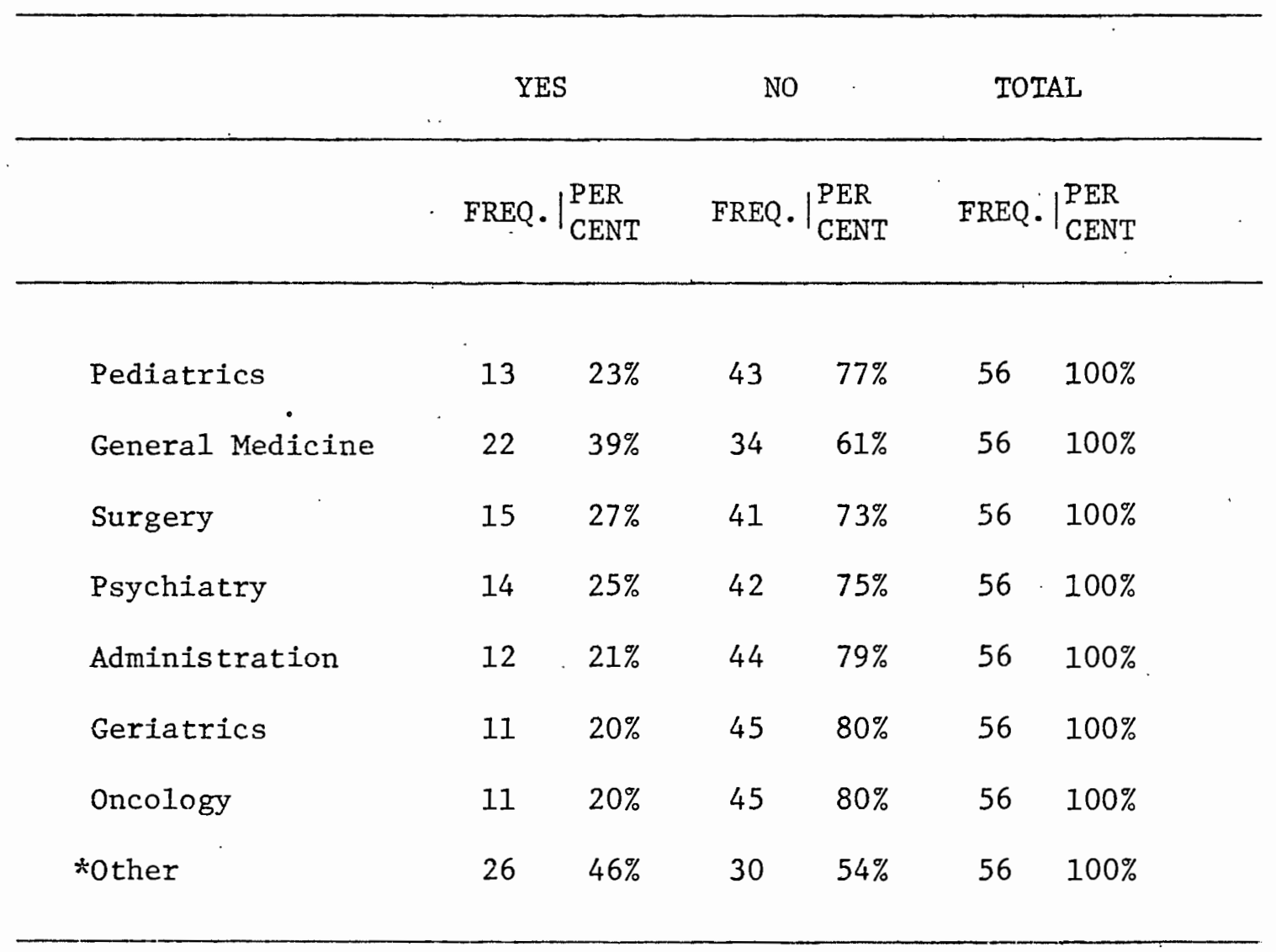

After examining the above table one can see the largest category of practice indicated was "other." This section was placed on the questionnaire to allow the respondents to identify areas of specialization which were not itemized on the data collec- 
tion instrument. The 26 responses received in the other category are itemized in Table $\mathrm{V}$.

TABLE $V$

*OTHER SPECIALTY AREAS OF PRACTICE

$\begin{array}{ll}\text { Burns } & 1 \\ \text { Cancer Rehabilitation } & 1 \\ \text { Cardiology } & 1 \\ \text { Ambulatory Care } & 3 \\ \text { Intensive Care } & 2 \\ \text { Emergency Room } & 3 \\ \text { Neurology } & 3 \\ \text { Ob/Gyn } & 3 \\ \text { Physiatry } & 5 \\ \text { Hemodialysis } & 4\end{array}$

1

1

1

3

2

3

3

3

5

4

TOTAL

Continuing in this section, it was asked what per cent of the surveyed social worker's case load was made up of terminally ill patients. The results of this question are recorded in Table VI. In examining this table, it can be observed that 41 (74\%) of the social workers studied had case loads which were made up of less than $30 \%$ terminally ill patients. Eight (14\%) of those surveyed had case loads which contained $30 \%$ terminally ill clients, two ( $4 \%$ ) 
of the study had caseloads which contained $70 \%$ terminal patients and one (2\%) of the respondents had a caseload made up of $90 \%$ terminally ill individuals.

TABLE VI

CASE LOADS AND TERMINALLY ILL PATIENTS

Per Cent of Case Load

Which is Terminally

Frequency Per Cent

Ill Patients

$\begin{array}{lll}0 \% & 16 & -29 \% \\ 10 \% & 19 & 34 \% \\ 20 \% & 6 & 11 \% \\ 30 \% & 8 & 14 \% \\ 40 \% & 4 & 07 \% \\ 50 \% & 0 & 00 \% \\ 60 \% & 0 & 00 \% \\ 70 \% & 2 & 04 \% \\ 80 \% & 0 & 00 \% \\ 90 \% & 1 & 02 \% \\ 100 \% & 0 & 00 \%\end{array}$

TOTAL :

56

$100 \%$

The next area of information requested on the questionnaire related to what per cent of the medical social worker's employment time was utilized in working with terminally ill patients and their 
families on a one to one basis. The Table VII illustrates the answers received.

TABLE VII

EMPLOYMENT TIME RELATED TO TERMINALLY ILL PATIENTS

Percent of Employment Time

Spent With Terminal Patients

and Their Families
Frequency Per Cent

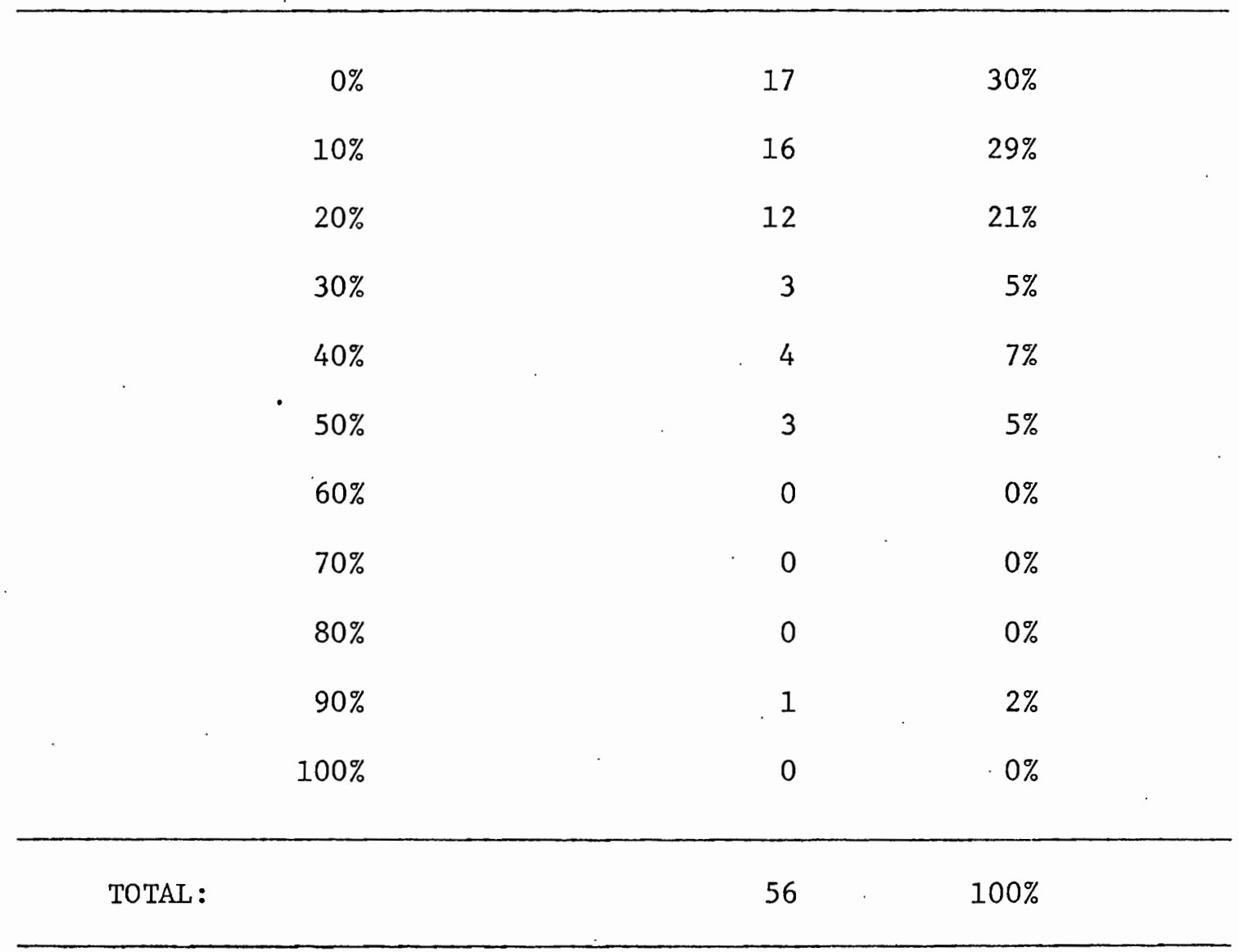

The last two questions of this section were specifically related to the participant's personal experience with terminally ill patients. The first question was directed toward finding out how many terminally ill patients the surveyed social workers had worked 
with in the last year. The second question extracted data regarding the total number of deaths the respondent's had ever wittnessed. These questions and their responses are contained in Tables VIII and IX.

\section{TABLE VIII}

EXPERIENCE WITH TERMINALLY ILL PATIENTS IN LAST YEAR.

Number of Patients Amount Per Cent

TOTAL:

TABLE IX

DEATHS ACTUALLY WITNESSED

Number of Deaths

Amount Per Cent

\begin{tabular}{lrr} 
None & 26 & $46 \%$ \\
$1-4$ & 20 & $36 \%$ \\
$5-8$ & 6 & $11 \%$ \\
$9-12$ & 1 & $2 \%$ \\
12 or more & 3 & $5 \%$ \\
\hline
\end{tabular}


Education and Training Related to Working With Termina11y III

Patients and Their Families.

The beginning question in this part of the data collection instrument addressed the issue of training related to thanatology while in graduate school. The results suggested 22 (39\%) of the MSWs surveyed had taken part in either counseling, seminars, or specific training related to death and dying, while enrolled in their MSW program. Thirty-four (61\%) had not been exposed to such training. It should be noted that some of the participants in the study went to graduate school before courses on death and dying were part of the social work curriculum.

The second question of this section was designed to measure the respondents' feelings regarding the type of training they received in their MSW program and how it equipped them to work with the terminally ill patients. Table $\mathrm{X}$ illustrates their responses.

\section{TABLE X}

MSW ADEQUATELY PREPARED FOR

WORKING WITH TERMINALLY ILL PATIENTS

Answer Categories

Frequency - Per Cent

Strongly Agree

Moderately Agree

Neutral

Moderately Disagree

Strongly Disagree
1

$2 \%$

7

$13 \%$

15

$27 \%$

23

$41 \%$

10

$18 \%$ 
Note that $2 \%$ strongly agreed and only $13 \%$ moderately agreed with the above statement; while $41 \%$ moderately disagreed and $18 \%$ strongly disagreed.

The final question used to gather data for this portion was constructed to see if any of the medical social workers surveyed had been involved in any training related to death and dying since the completion of their MSW. Forty-three (77\%) had, and 13 (23\%) had not been involved in such training.

Specific Practice Data Related to Working With Terminally Ill Patients and Their Families

The questions which made up this part of the questionnaire extracted attitudinal data regarding the social worker and his practice with terminal patients and their families. The first question addressed the issue of whether the patient should be informed of his impending death. The responses are in Table XI.

TABLE XI

PATIENT SHOULD ALWAYS BE TOLD HE IS TERMINALLY ILL

\begin{tabular}{lcc}
\hline Answer Categories & Frequency & Per Cent \\
Strongly Agree & 20 & $36 \%$ \\
Moderately Agree & 23 & $41 \%$ \\
Neutral & 8 & $14 \%$ \\
Moderately Disagree & 4 & $7 \%$ \\
Strongly Disagree & 1 & $2 \%$ \\
\hline
\end{tabular}


In Table XI it can be seen that $77 \%$ of the respondents agree in some fashion that the terminal patient should be informed of his situation. Eight or $14 \%$ were neutral and 5 ( $8 \%)$ moderately or strongly disagreed that the patient should always be told.

Regarding whose responsibility it is to tell the patients they have a terminal condition see Table XII.

\section{TABLE XII}

RESPONSIBILITY FOR INFORMING PATIENTS OF TERMINAL CONDITION

\begin{tabular}{lcc}
\hline Answer Categories & Frequency & Per Cent \\
\hline $\begin{array}{l}\text { Physician } \\
\text { Family }\end{array}$ & 48 & $86 \%$ \\
$\begin{array}{l}\text { Social Worker } \\
\text { The best equipped person } \\
\text { which will vary }\end{array}$ & 2 & $5 \%$ \\
\hline
\end{tabular}

With reference to how important the social workers felt it was to have the family present at the patient's time of death, $37(66 \%)$ thought it was very important, 8 (14\%) indicated it was moderately important, $1(2 \%)$ said it was not important at all, and 10 (18\%) were undecided.

Further in this section, the respondents were asked if they felt they needed any special skills or training to deal with terminal patients and their families. Fifty-three (95\%) said "yes," special training was required to work with this type of client. 
Regarding social workers' preference for any specific type of client, $14(20 \%)$ said they would rather work with the dying patient's family, $5(9 \%)$ replied they would prefer to work with the terminally ill patient and 37 (66\%) indicated it made no difference.

The next items used in this part of the data collection instrument were two short essay questions. The first question asked, "What do you feel is the most important thing you can offer a terminally ill patient as a medical social worker. Responses ranged from "a social work relationship" to "just being there when needed." The most prevalent comments made were: emotional support, understanding, sympathy, and sharing of the patient's feelings. Other answers which differed from the majority were: an unhurried contact, helping significant others to be supportive to patient, and affirming the value of the patient's life. In conjunction with the above item, a follow-up question was asked stating, "Would you describe what you feel are the essential skills needed to work with the terminally ill patients and their families?" The most frequently reported response was being able to deal with feelings about one's death. Other skills mentioned were being a good listener, being empathetic, possessing good case work skills, having knowledge of the disease and dying process and lastly, being sensitive to underlying conflict between family members.

The last question contained in this section was designed to examine the notion that when individuals work in a medical setting where death and terminally ill patients are encountered on a frequent 
basis they become insensitive to the needs of the dying patient and his/her family. See Table XIII for a tabulation of the answers given regarding this question.

\section{TABLE XIII}

FREQUENT ENCOUNTER WITH TERMINAL PATIENTS

MAKES ONE INSENSITIVE TO THEIR NEEDS

\begin{tabular}{lcc}
\hline Answer Categories & Frequency & Per Cent . \\
\hline Strongly Agree & 10 & $18 \%$ \\
Moderately Agree & 16 & $29 \%$ \\
Neutral & 16 & $29 \%$ \\
Moderately Disagree & 10 & $18 \%$ \\
Strongly Disagree & 4 & $7 \%$ \\
\hline
\end{tabular}

Personal Data Related to Death and Dying

For a descriptive analysis of the responses given in this part of the questionnaire see Tables XIV, XV, XVI, XVII, XVIII, and XIX. 
TABLE XIV

\section{RELIGOSITY}

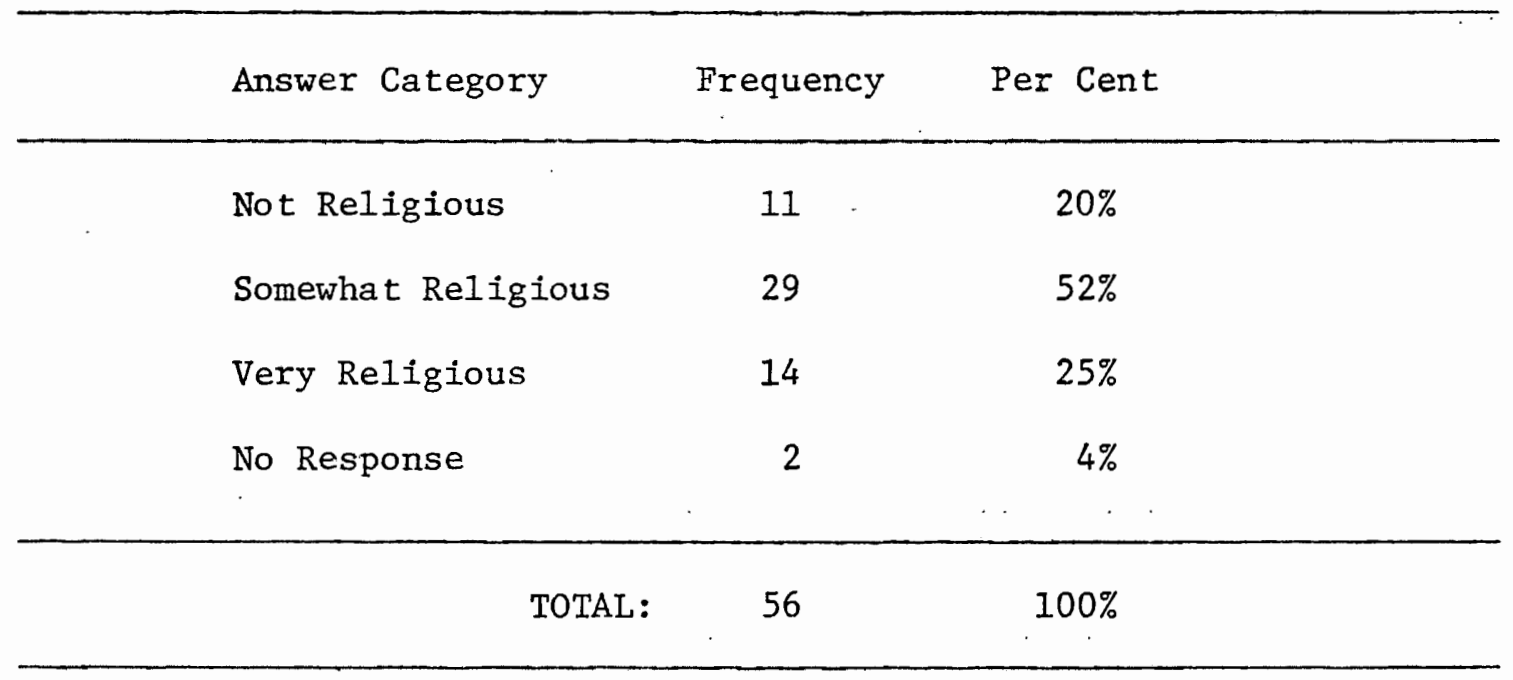

TABLE XV

BELIEF IN LIFE AFTER DEATH

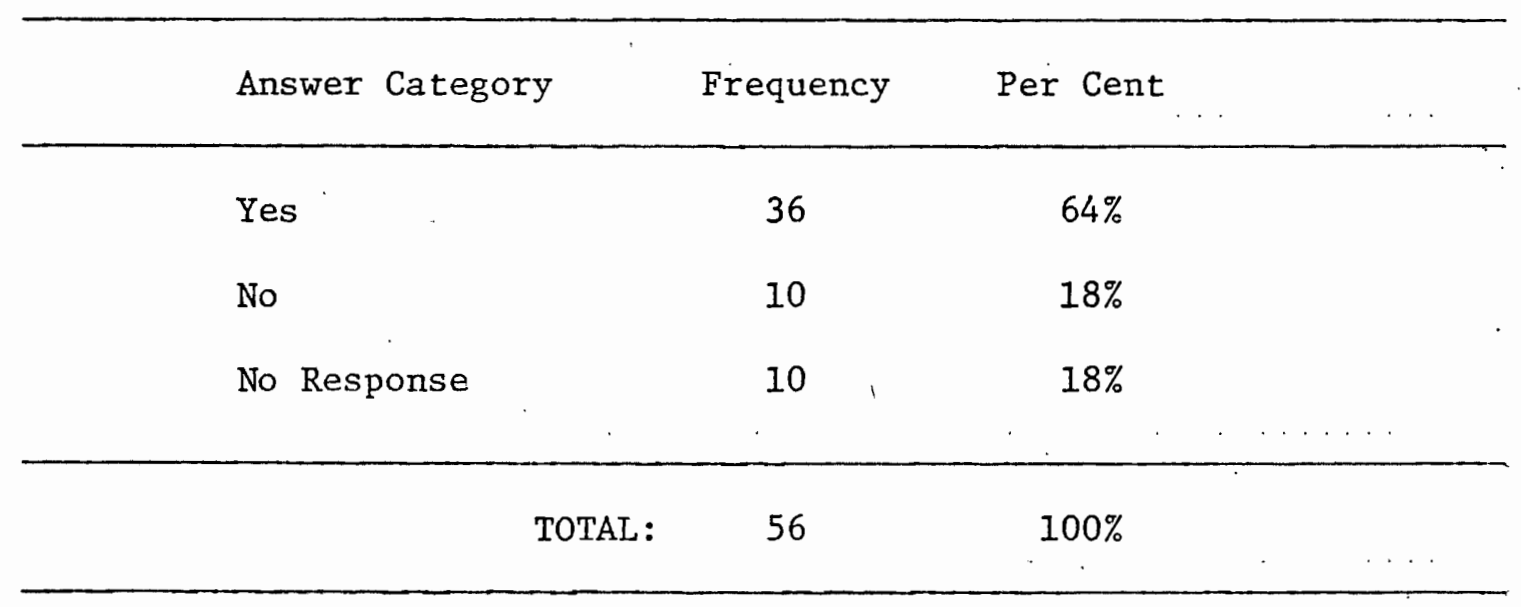


TABLE XVI

FEAR OF DEATH

\begin{tabular}{lcc}
\hline Answer Category & Frequency & Per Cent \\
\hline A1ways & 4 & $7 \%$ \\
Sometimes & 30 & $54 \%$ \\
Very Seldom & 19 & $34 \%$ \\
Never & 3 & $5 \%$ \\
\hline & 56 & $100 \%$ \\
\hline
\end{tabular}

TABLE XVII

FREQUENCY OF PERSONAL THOUGHTS TOWARD DEATH

\begin{tabular}{|c|c|c|}
\hline Answer Category & Frequency & Per Cent \\
\hline- & & \\
\hline Once a day & 6 & $11 \%$ \\
\hline Once a week & 11 & $20 \%$ \\
\hline Once a month & 29 & $52 \%$ \\
\hline Once a year & 10 & $18 \%$ \\
\hline Never & 0 & $0 \%$ \\
\hline TOTAL: & 56 & $100 \%$ \\
\hline
\end{tabular}


TABLE XVIII

TERMINAL ILLNESS---WANTING DOCTOR TO TELL YOU

\begin{tabular}{lcc}
\hline Answer Categories & Frequency & Per Cent \\
\hline Immediately & 52 & $93 \%$ \\
Not tell you & 00 & $00 \%$ \\
$\begin{array}{l}\text { Tell your family } \\
\text { first } \\
\text { Tell you over a } \\
\text { period of time } \\
\text { TOTAL: }\end{array}$ & 00 & $00 \%$ \\
\hline
\end{tabular}

TABLE XIX

FUTURE FUNERAL ARRANGEMENTS MADE BY RESPONDENTS

Answer Categories Frequency Per Cent

Yes

19

$34 \%$

No

36

$64 \%$

No Response

1

$2 \%$

TOTAL: $\quad 56 \quad 100 \%$

In reviewing the previous six tables, it is evident that $30(54 \%)$ of those surveyed sometimes fear death, however 19 (34\%) 
fear death very seldom. Forty-six (83\%) of the population think about their own death at least once a month and 17 (31\%) consider this topic at least once a week. Of all the social workers questioned, $93 \%$ wanted to be immediately told if they had a terminal illness and $4 \%$ wanted to be informed over a period of time. Nineteen (34\%) of the survey have made funeral arrangements for themselves while 36 (64\%) have not.

Regarding religious matters and life after death, $52 \%$ of those studied stated they were somewhat religious, $20 \%$ considered themselves not religious, and $25 \%$ implied that they were very religious. Thirty-six (64\%) indicated they believed in life after death and $18 \%$ said they did not.

Data Related to Specific Place of Employment

The next section dealt with (a) the competency of general and social work staff to meet the needs of dying patients and their families and (b) the adequacy of training which exists for general and social work staff in this area. See Table XX on the next page. 
TABLE XX

COMPETENCY OF PRIMARY CARE STAFF TO MEET NEEDS

OF TERMINALLY ILL PATIENTS AND THEIR FAMILIES

Answer Categories

Frequency Per Cent

Very Competent

5

$9 \%$

Moderately Competent

15

$27 \%$

Neutral

28

$50 \%$

Moderately Incompetent

7

$13 \%$

Very Incompetent

1

$2 \%$

TOTAL :

56

$100 \%$

Al1 of the respondents were also asked to rate their own department of social work in terms of whether it offered enough staff training in this area. The results are contained in Table XXI on the following page. 
TABLE XXI

SOCIAL WORK DEPARTMENT ITS OFFERING OF THANATOLOGY TRAINING

Answer Category

Frequency Per Cent

Offers none at all

1

15

$27 \%$

2

10

$18 \%$

3

24

$43 \%$

4

6

$11 \%$

5

1

$2 \%$

Offers more than enough

TOTAL:

56

$100 \%$

Addressing the issue of improvement in services to the dying patient by the medical facility employing the respondents in this survey, see Table XXII.

TABLE XXII

THANATOLOGY SERVICE IMPROVEMENT NEEDED BY PLACE OF EMPLOYMENT

Answer Category

Frequency

Per Cent

Strongly Agree

13

$23 \%$

Moderately Agree

26

$46 \%$

Neutral

15

$27 \%$

Moderately Disagree

2

$4 \%$

Strongly Disagree

0

$0 \%$ 
Reducing this frame of reference, all of the social workers were also asked if they felt the death and dying services provided by the social work department in which they now worked could be improved. Their responses are in Table XXIII.

TABLE XXIII

DEATH AND DYING SERVICES BY SOCIAL WORK DEPARTMENTS IN NEED OF IMPROVEMENT

\begin{tabular}{|c|c|c|}
\hline Answer Category & Frequency & Per Cent \\
\hline Strongly Agree & 12 & $2: 1 \%$ \\
\hline Moderately Agree . & 20 & $36 \%$ \\
\hline Neutral & 19 & $34 \%$ \\
\hline Moderately Disagree & 4 & 7 \\
\hline Strongly Disagree & 1 & 2 \\
\hline TOTAL: & 56 & $100 \%$ \\
\hline
\end{tabular}

Regarding inservice thanatology training for primary care staff, $44(79 \%)$ said not enough was offered at their place of employment. Twelve (22\%) disagreed with this conclusion.

The last question asked in this section was related to how the respondents felt about technology getting in the way of the patient's being able to experience death in a dignified and humane way. The question read: "According to several authorities, medical technology with all of its sophisticated equipment and procedures has gotten in the way of allowing the patient to experience his/her death in a 
dignified way." Do you agree or disagree with this statement? The ratio of agree to disagree was three to one in favor of agree. Those agreeing felt the medical process does dehumanize patients and removes some of the privacy one needs when facing death and its finality. Of the respondents who disagreed most felt technology was a necessary accoutrement of today's medical profession, and saw the wishes of others to keep the patient alive at all expense as the precipitant of death being experienced in an undignified way. 


\section{CHAPTER FIVE}

\section{CONCLUSIONARY SUMMARY AND IMPLICATIONS}

This study was developed to assess. (MSW) medical social workers' attitudes toward death and other related matters such as training in thanatology, effectiveness of hospital staff to deal with the terminally ill patient, and social work practice related to terminal care. A questionnaire was sent to all of the fifty-eight (MSW) medical social workers currently employed at the eleven major medical hospitals in Portland, Oregon, during the month of March, 1977. Fifty-six questionnaires were returned, and it was from these fifty-six that the following inferences were made. The instrument used to collect data for this study was designed and pretested by this researcher. Also contained in this report is a review of the literature regarding general methods used to gather attitudinal data in relation to death, general population attitudes toward death, attitudes about death from various health care professionals, social workers' attitudes toward death and thanatology training in social work education.

\section{Specific Conclusions}

In general it was found of those social workers surveyed, that few displayed any persistent fear of death. Most indicated they thought of their own death less than once a month. A sizeable proportion of the respondents believed in life after death and identified themselves as either somewhat religious or very religious. Other 
conclusions which can be drawn about the social workers surveyed in this study are that a significant number wanted to be told if they had a terminal illness, and several have made future funeral arrangements for themselves.

Demographically speaking, the majority of those surveyed represented a younger age constituent; also a higher proportion of the population studied was women as opposed to men. This suggest that the number of male medical social workers (MSW) is not equally represented in the Portland hospitals. Most of the respondents have been in practice four years or less and are still employed at their first or second medical social work position. Regarding the total amount surveyed, many have been involved in more than one practice specialty since the beginning of their hospital employment.

Several (71\%) of the social workers in this study indicated they currently are involved in some type of an ongoing contact with terminally ill patients, yet few (19\%) really spend a great amount of their employment time working with this type of client. The majority $(81 \%)$ of the individuals surveyed stated they have worked with several dying patients in the last year, however, few of the respondents indicated they had witnessed many deaths in their total career as a medical social worker. This is in keeping with literature currently available regarding social workers and terminally ill clients. $^{145}$

In reference to past training to deal with this type of client, the majority (61\%) said they had not been able to obtain any thanatology course work in graduate school. Also a high proportion of those 
involved in this survey replied that the general social work training which they received in their MSW program did not adequately prepare them to work with the terminally ill patient and his/her family. In spite of the lack of thanatology training experienced by most of the respondents in graduate school, a majority (77\%) has subsequently involved itself in post master's education to ameliorate this informational deficit.

From a practice venue, a large proportion (77\%) of the social workers in this study felt the patient should always be told he/she is dying; they also overwhelmingly agreed (86\%) it was the physician's responsibility to convey this information to the terminal patient. A large per cent $(66 \%)$ of the study participants indicated it was important for the family to be present at the patient's death, while most stated it made no difference who they worked with, the family or the terminal patient. The most salient conclusion which can be gleaned from the data regarding social work practice and terminal patients is that almost al.1 respondents (95\%) indicated that special skills were needed to work with dying patients and their families.

Continual exposure to terminally. ill patients was not considered a stimulus for making social workers insensitive to the needs of the dying patient. Of those surveyed, a majority (61\%) agreed that emotional support and understanding were the most important things a medical social worker could offer someone who was dying. It was also stated that "coming to grips with one's own terminality" was the most essential skill social workers need to master before working with terminally ill patients. Such a conclusion is consistent with Iiterature previously noted in this paper. 146 
Last1y, $69 \%$ of the respondents indicated they felt the services provided by their hospital to the dying patient could be improved. Also, $79 \%$ said their place of employment did not offer enough thanatology training for its primary care staff (doctors, nurses, social workers). This, however, is in contrast with an opinion voiced on the questionnaire which suggests that $86 \%$ of the total survey identified the primary care staff of their hospital as competent in meeting the needs of the dying patient.

More specifically, it was further revealed that many of this study's participants felt a need for more social work training related to death and dying on a departmental level. A consensus of the social workers surveyed also indicated that services currently being provided to terminally ill patients by their social work departments could be improved.

\section{Implications}

The implications presented here cover such categories as. graduate education, inservice training and service deliverỵ. Many of the things said will no doubt resonate of previous calls for. change; however, it is this researcher's opinion that repetition brings about cognitive awareness which facilitates needed alteration and growth.

With respect to the research data contained in this report, it can be suggested that graduate schools of social work do not provide enough thanatology training in spite of the fact that the majority of social workers in this survey now see working with terminal 
patients as an area of practice which requires special skills. Most students presently do not have the opportunity to acquire this type of knowledge in their MSW program and are forced to obtain it after they have completed their graduate study.

Regarding service delivery and practice concerns, it is essential that medical social workers come to grips with their own death before they can comfortably work with terminal patients. Important to the terminally ill patient is the conveyance of understanding and empathy by the social work staff. Social workers need to be the one staff member who will sit down and fully explore the feelings of the terminal patient without rush or conveying a predisposition for being somewhere else. Services to the dying patient need to be continually evaluated to assess their effectiveness and relevance. This should be done at the general staff level as well as at the social work departmental level.

In reference to hospitals and medical social work departments, ongoing training around the subject of death and dying needs to be conducted via an in-service model. Many social workers now express a need for this type of learning experience rather frequently. Such education is more job related and individually relevant than some of the course work offered at the university level.

Perhaps the most important implication of this study is the awareness of need for more research identifying social workers' attitudinal base regarding this topic, needs for relevant training, and changes in social work practice which reflect the concerns of the terminally ill patient and his family. At this point in time, 
a study of this subject matter can only be considered exploratory. Before specific facts, regarding this area of investigation, can be collectively agreed upon, more research needs to be conducted and shared with the academic community. It is to such an end that this researcher presents this study as a springboard for future inquiries. 


\section{REFERENCES CITED}

1. Elisabeth Kubler-Ross, On Death and Dying (New York: MacMillan Publishing Co:, Inc., 1969).

2. Robert E. Kavanaugh, Facing Death (Baltimore: Penguin Books, Inc., 1974)

3. John Langone, Vital Signs: The Way We Die in America (Boston: Little, Brown and Company,.1974).

4. Edwin S. Shneidman, "You and Death," Psychology Today (June, 1971).

5. Robert T. Kurlychek, "Assessment of Attitudes Toward Death and Dying: A Critical Review of Some Available Methods," Omega 9 (1) $(1978-79): 37$.

6. G. S. Ha11, "A Study of Fears," American Journal of Psychology 8 (1896):

7. W. C. Middleton, "Some Reactions Toward Death Among College Students," Journal of Abnormal and Social Psychology 31 (1936): 165-173.

8. Shneidman, pp. 43-45; 74-80.

9. Kurlychek, p. 38 .

10. M. Nagy, "The Child's Theories Concerning Death," Journal of Genetic Psychology 73 (1948): 3-27.

11. A. E. Christ, "Attitudes Toward Death Among a Group of Acute Geriatric Patients," Journal of Gerontology 16 (1961): 56-59.

12. Kurlychek, p. 39.

13. E. Lichtenstein, "Techniques for Assessing Outcomes in Psychotherapy," Advances in Psychological Assessment, 2, P. McReynolds (ed.) (San Francisco: Jossey-Bass, 1971).

14. Kurlychek, p. 39.

15. D. I. Templer, "The Relationship Between Verbalized and NonVerbalized Death Anxiety," Journal of Genetic Psychology 119 (1971): 211-214. 
16. Kurlychek, p. 39.

17. Louis S. Dickstein, "Attitudes Toward Death, Anxiety and Socia1 Desirability," Omega 8(4) (1977-78): 369.

18. Ibid., p. 369 .

19. Ibid., p. 369 .

20. Ibid., p. 369.

21. Ibid., p. 369 .

22. Ibid., p. 377 .

23. Ibid., p. 377.

24. Kurlychek, p. 37.

25. Dickstein, p. 377.

26. Herman Feifer, "Death" in Norman L. Farberow, Taboo Topics (New York: Atherton Press, 1963).

27. Ernest Becker, 'The Denial of Death:! (New York: The Free Press, 1975), p. 15.

28. Mannes, Marya, 'Last Rights: (New York: Signet Books, 1973), pp. 138-139.

29. David S. Kazzaz and Raymond Vickers, "Geriatric Staff Attitudes Toward Death," Journal of American Geriatrics Society 16 (December, 1968): 1364 .

30. Ibid., p. 1364 .

31. Ibid., p. 1364 .

32. Ibid., p. 1364 .

33. Ibid., p. 1364.

34. Shneidman, pp. 43-45; 74-80.

35. R. Kastenbaum and Ruth Aisenberg, The Psychology of Death (New York: Springer Publishing Company, 1976), p. 57.

36. Shneidman, pp. 43-45; 74-80.

37. D. Cappon, "Attitudes on Death," Omega 1 (May, 1970): pp. 103-108. 
38. Kastenbaum \& Aisenberg, p. 82.

39. Ibid., p. 82 .

40. E. Mansell Pattison, The Experience of Dying. (Englewood Cliffs: Prentice-Hall, Inc., 1977), pp. 12-13.

41. M. Priscilla Rea, Shirley Greenspoon and Bernard Splika, "Physicians and the Terminal Patient: Some Selected Attitudes and Behavior," Omega 6 (1974-1975), p. 292.

42. Diane Caldwell and B. L. Mishara, "Research on Attitudes of Medical Doctors Toward the Dying Patient: A Methodological Problem," Omega 3 (November 1972): p. 343.

43. Ibid., p.342.

44. Rea, Greenspoon, and Splika, p. 292.

45. D. Peretz, A. C. Carr, B. Schoenberg, and A. H. Kutscher, "A Survey of Physicians' Attitudes Toward Death and Bereavement," Journal of Thanatology. 1 (1971): 91-100.

46. Rea, Greenspoon and Splika, p. 292.

47. T. A. Travis, R. Noyes, and D. R, Brightwe11, International Journal of Psychiatry and Medicine, 5 (1974): 17-26

48. R. Schulz and D. Aderman, "How Medical Staff Copes With Dying Patients: A Critical Review," Omega 7(1) (1979): p. 12.

49. Ibid., p. 12 .

50. Ibid., p. 12 .

51. Ibid., p. 12 .

52. A. M. Kasper, "The Doctor and Death," in H. Feifel (ed.), The Meaning of Death (New York: McGraw Hill, 1969), p. 262.

53. Schulz and Aderman, p. 12 .

54. P. B. Livingston and C. N. Zimet, "Death Anxiety, Authoritarianism and Choice of Specialty in Medical Schools," Journal of Nervous Mental Disease. 140 (1965): 222-230.

55. Kazzaz and Vickers, p. 1370.

56. Schulz and Aderman, p. 12.

57. Ibid., p. 12 . 
58. Ibid., p. 12 .

59. Erwin Ringle, "The Problem of Death Repression in Medical Training," Dynamische Psychiatrie, 8 (1975): 143-158.

60. Rea, Greenspoon, and Splika, pp. 291-302.

61. Ibid., p. 293.

62. L. Stratton and M: Hammon, "Physicians' Attitudes On Death and Dying," paper presented in Social Work Research class, Portland State University, School of Social Work, Winter, 1975.

63. David Hendin, Death as a Fact of Life (New York: Warner Paperback, 1973), p. 128.

64. Ibid, p. 128.

65. Rea, Greenspoon, and Splika, p. 294.

66. Schulz and Aderman, pp. 13-14.

67. Ibid., p. 12 .

68. Kubler-Ross, pp . 23-37.

69. B. G. Glasser and A. L. Strauss, Awareness of Dying (Chicago: Aldine, 1965), pp. 119-125.

70. Schulz and Aderman, p. 12.

71. D. Oken, "What to Tel1 Cancer Patients," J.A.M.A. 175 (1961): pp. 86-94.

72. W. T. Fitts, and I. S. Ravdin, "What Philadelphia Physicians Tell Patients With Cancer," J.A.M.A. 153 (1953): 901-904.

73. Schu1z and Aderman, p. 13.

74. R. Noyes, Jr., "The Art of Dying," Perspectives in Biological Medicine 14 (1971): p.p. 432-447.

75. Shulz and Aderman, p. 13.

76. Kubler-Ross, p.11-37.

77. Glasser and Strauss, 1965.

78. Shulz and Aderman, P. 13. 
79. E.M. Litin, "What Shall We Tell the Cancer Patient?, A Psychiatrist's View," Proceedings of Mayo Clinic 35 (1960): pp.247-250.

80. S. O. Hoerr, "Thoughts on What to Tell the Patient With Cancer," Cleveland Clinic Quarterly, 30 (1963): 11-16.

81. Schulz and Aderman, p. 13.

82. D. Oken, "The Physician, The Patient and Cancer,". Illinois Medical Journa1, 120 (1961): 333-334.

83. Oken, D., J.A.M.A., pp. 86-94.

84. D. Schreibaum, "Approaches and Developments on the Study of Attitudes to Death," Israel Annals of Psychiatry and Related Disciplines 13 (September, 1975): pp. 259-269.

85. Glasser, and Strauss, p. vii.

86. Dianne Fochtman, "A Comparative Study of Pediatric Nurses' Attitudes Toward Death," Iife Threatening Behavior 4 (Summer 1974): p. 107 .

87. Ruth A. Ansell, "If You Were Dying," in R. Caughill (ed.), The Dying Patient (Boston: Little, Brown and Company, 1976), p. 50.

88. David Popoff, "What Are Your Feelings About Death and Dying," Nursing (August, 1975): pp. 16-24.

89. Kubler-Ross, p. 23.

90. Glasser and Strauss, pp. 226-234.

91. Christine Gow and J. Ivan Williams, "Nurses' Attiutudes Toward Death and Dying: A Causal Interpretation," Social Science and Medicine 11 (1977): p. 191.

92. Rita Caughil1, The Dying Patient (Boston: Little, Brown, and Company, 1976), p. 51.

93. J. C. Quint, Nurse and the Dying Patient (New York: MacMillan Co., 1967).

94. Gow and Williams, p. 198.

95. David Lester, C. Getty, and C. Kneis1, "Attitudes of Nursing Students and Nursing Faculty Toward Death," Nursing Research 23 (Jan-Feb., 1974): p. 53.

96. R. Yeaworth, F. Kapp, and C. Winget, "Attitudes Toward the Dying Patient," Nursing Research 23 (Jan.-Feb., 1974): p. 24. 
97. Avery Weisman, The Realization of Death (New York: Aronson, 1974), p. 192.

98. Caughil1, p. 51.

99. Yeaworth, Kapp, and Winget, p. 24.

100. C. Lutticken, K. Shepard, and N. Davies, "Attitudes of Physical Therapists Toward Death and Terminal Illness," Physical Therapy 54 (March, 1974): p. 226.

101. G. Reznikoff, "Attitudes Toward Death: A Comparison of Nursing Students and Graduate Students," Nursing Research 20 (1971): pp. 503-508.

102. Shniedman, June, 1971.

103. L. O. Bascue, R. Lawrence, and J. Sessions, "Death Attitudes and Experiences of Rehabilitation Counselors," Suicide and LifeThreatening Behavior 8 (Spring, 1978): 14 .

104. J. Pearlman, B. Stotsky, and J. R. Dominick, "Attitudes Toward Death Among Nursing Home Personnel," Journal of Genetic Psychology 114 (1969): 63 .

105. Eda G. Goldstein, "Social Case Work and the Dying Person," Social Case Work 54 (December, 1973): 604.

106. R. A. Lohman, "Dying and the Social Responsibility of Institutions," Social Case Work 58 (November, 1977): 538.

107. Erich Lindemann, "Symptomatology and Management of Acute Grief," in Crisis Intervention: Selected Readings, (ed.) Howard Parad (New York: Family Service Association of America, 1965); p. 7.

108. Howard Parad (ed.), Crisis Intervention: Selected Readings (New York: Family Service Association of America, 1965), p. 53.

109. Ibid., p. 53 .

110. Stanley Goldberg, "Family Tasks and Reactions in the Crisis of Death," Social Case Work 54 (July, 1973): 398.

111. Ibid., p. 401.

112. Goldstein, p. 601.

113. Ibid., p. 605.

114. Ibid., p. 605. 
115. B. Simos, "Grief Therapy to Facilitate Healthy Restitution," Social Case Work 58 (June, 1977): 341.

116. Ibid., p. 341 .

117. Ibid., p. 341.

118. Ibid., p. 341.

119. Ibid., p. 341.

120. Leon Ginsberg, "The Social Worker's Role," in Social Work With the Dying Patient and the Family, (ed.) E. Prichard (New York: Columbia University Press, 1977), p. 1.

121. Car1 Pilsecker, "Help For the Dying," Social Work 20 (May, 1975): p. 190 .

122. Ginsberg, p. 5 .

123. Ibid., p. 5 .

124. Pilsecker, p. 190.

125. Ibid., p. 190.

126. Ibid., p..194.

127. Rosalind Miller, "Teaching Death and Dying Content in the Social Work Curriculum," in Social Work With the Dying Patient and the Family, (ed.) E. Prichard (New York: Columbia University Press, 1977), p. 289.

128. Ibid., p. 289.

129. Miller, p. 290.

130. E. Prichard (ed.), Social Work With the Dying Patient and the Family. (New York: Columbia University Press, 1977).

131. L. Lister and H. Gochros, "Preparing Students for Effective Social Work Practice Related to Death," Journal of Education for Socia1 Work 12 (Winter, 1976) : 85.

132. Eda Goldstein, "Teaching a Social Work Perspective on the Dying Patient and His Family," in Social Work. With the Dying Patient and the Family, (ed.) E. Prichard (New York: Columbia University Press, 1977).

133. Cassidy, Helen, "Helping the Social Work Student Deal With Death and Dying," in Social Work With the Dying Patient and the Family, (ed.) E. Prichard (New York: Columbia University Press, 1977). 
134. Miller, p. 289.

135. Goldstein, p. 302.

136. Ibid!, p. 305.

137. Ibid., p. 309.

138. Cassidy, p. 321.

139. Ibid., p. 317.

140. Miller, pp. 290-291.

141. Ibid., p. 297.

142. Lister and Gochros, p. 85.

143. Ibid., p. 87.

144. Ibid., p. 90.

145. Pilsecker, p. 190.

146. Cassidy, p. 321. 


\section{B IBLIOGRAPHY}

Ansel1, Ruth A. "If You Were Dying," in R. Caughill (ed.), The Dying Patient, Boston: Little, Brown and Company, 1976.

Bascue, L. $\therefore$ 0, R. Bawrence, J. Sessions. "Death Attitudes and Experiences of Rehabilitation Counselors," Suicide and Life Threatening Behavior. 8 (Spring, 1978), pp, 14-17.

Becker, Ernest. The Denial of Death. New York: The Free Press, 1975.

Caldwell, Diane and B. L. Mishara. "Research on Attitudes of Medical Doctors Toward the Dying Patient: A Methodological Problem," Omega. 3 (November, 1972), pp, 341-346.

Cappan, D, "Attitudes on Death," Omega. 1 (May, 1970), pp. 103-108.

Cassidy, Helen. "Helping the Social Work Student Deal With Death and Dying," in Social Work With the Dying Patient and the Family, E. Prichard (ed.). New York: Columbia University Press, 1977.

Caughill, Rita, The Dying Patient. Boston; Little, Brown; and Company, 1976 .

Christ, A. E. "Attitudes Toward Death Among a Group of Acute Geriatric Patients," Journal of Gerontology. 16 (1961), pp. 56-59.

Dickstein, Louis S. "Attitudes Toward Death, Anxiety, and Social Desirability," Omega. 8(4) (1977-78), pp. 369-377.

Feifer, Herman. "Death," in Norman L. Farberow, Taboo Topics. New York: Atherton Press, 1963.

Fitts, W.T., I. S. Ravdin. "What Philadelphia Physicians Tell Patients With Cancer," J.A.M.A. 153 (153), pp. 901-904.

Fochtman, Dianne. "A Comparative Study of Pediatric Nurses' Attitudes Toward Death;" Life Threatening Behavior. 4 (Summer, 1974), pp. $107-117$.

Ginsberg, Leon. "The Social Worker's Role," in Social Work With the Dying Patient and the Family, E. Prichard (ed.). New York: Columbia University Press, 1977. 
Glasser, B. G. and A. L. Strauss. Awareness of Dying. Chicago: Aldine, 1965.

Goldberg, Stanley. "Family Tasks and Reactions in the Crisis of Death," Social Case Work. 54 (July, 1973), pp. 398-405.

Goldstein, Eda G. "Social Case Work and the Dying Person," Social Case Work. 54 (December, 1973), pp. 601-608.

Goldstein, Eda. "Teaching a Social Work Perspective on the Dying Patient and His Family," in Social Work With the Dying Patient and the Family, E. Prichard (ed.). Hew York: Columbia University Press, 1977.

Gow, Christine and J. Ivan Williams. "Nurses Attitudes Toward Death. and Dying," Social Science and Medicine. 11 (1977), pp. 191-198.

Ha11, G. S. "A Study of Fears," American Journal of Psychology.

8 (1896), PP. 147-249.

Hendin, David. Death as a Fact of Life. New York: Warner Paperback, 1973.

Hoerr, S. 0. "Thoughts on What to Tell the Patient With Cancer," Cleveland Clinic Quarterly. 30 (1963), pp. 11-16.

Kasper, A. M. "The Doctor and Death," in H. Feifer (ed.), The Meaning of Death. New York: McGraw Hil1, 1969.

Kastenbaum, R. and Ruth Aisenberg. The Psychology of Death, New York: Springer Publishing Company, 1976.

Kavanaugh, Robert.E. Facing Death. Baltimore: Penguin Books, Inc., 1974.

Kazzaz, David S. and Raymond Vickers. "Geriatric Staff Attitudes Toward Death," Journal of American Geriatrics Society. 16 (December, 1968), pp. 1364-1371.

Kubler-Ross, Elisabeth. On Death and Dying. New York: MacMillan Publishing Co., Inc., 1969.

Kurlychek, Robert T. "Assessment of Attitudes Toward Death and Dying: A Critical Review of Some Available Methods," Omega. 9 (1978-79), pp. 37-47.

Langone, John. Vital Signs: The Way We Die in America. Boston: Little, Brown and Company, 1974 .

Lester, D., C. Getty. and C. Kneis1. "Attitudes of Nursing Students and Nursing Faculty Toward Death," Nursing Research. 23 (Jan.Feb., 1974), pp. 50-53. 
Lichtenstein, E. "Techniques for Assessing Outcomes in Psychotherapy," Advances in Psychological Assessment, 2, P. McReynolds (ed.). San Francisco: Jossey-Bass, 1974.

Lindemann, Erich. "Symptomatology and Management of Acute Grief," in Crisis Intervention: Selected Readings, Howard Parad (ed.). New York: Family Service Association of America, 1965.

Lister, L. and H. Gochros. "Preparing Students for Effective Social Work Practice Related to Death," Journal of Education for Social. Work. 12 (Winter, 1976), pp. 85-90.

Litin, E.M. "What Sha11 We Tell the Cancer Patient? A Psychiatrist's View," Proceedings of the Mayo Clinic. 35 (1960), pp. 247-250.

Livingston, P. B. and C. N. Zimet. "Death Anxiety, Authoritarianism and Choice of Specialty in Medical Students," Journal of Nervous Mental Disease. 140 (1965), pp. 222-230.

Lohman, R. A. "Dying and the Social Responsibility of Institutions," Socia1 Case Work; 58 (November, 1977), pp. 358-545.

Lutticken, C., K. Shepard and N. Davies. "Attitudes of Physical Therapists Toward Death and Terminal IIlness," Physical Therapy, 54 (March, 1974), pp. 226-231.

Mannes, Marya. Last Rights. New York: Signet Books, 1973.

Middleton, W. C. "Some Reactions Toward Death Among College Students," Journal of Abnormal and Social Psychology. 31 (1936), pp. 165-173.

Miller, Rosalind. "Teaching Death and Dying Content in the Social Work Curriculum," in Social Work With the Dying Patient and the Family, E. Prichard (ed.). New York: Columbia University Press, 1977 , pp. 289-299.

Nagy, M. "The Child's Theories Concerning Death," Journal of Genetic Psychology. 73 (1948), pp. 3-27.

Noyes, J. R. "The Art of Dying," Perspectives in Biological Medicine. 14 (1971), pp. 432-447.

Oken, D. "The Physician, the Patient, and Cancer," Illinois Medical Journal. 120 (1961), pp. 333-334.

Oken, D. "What to Tell Cancer Patients," Journal of the American Medical Association. 175 (1961), pp. 86-94.

Parad, Howard (ed.). Crisis Intervention: Selected Readings. New York: Family Service Association of America, 1965. 
Pattison, E. Manse11. The Experience of Dying. Englewood Cliffs:

Prentice Hall, Inc., 1977.

Pearlman, J., B. Stotsky, and J.R. Dominick. "Attitudes Toward Death Among Nursing Home Personnel," Journal of Genetic Psychology. 114 (1969), pp. 63-75.

Peretz, D., A.C. Carr, B. Schoenberg, and A. H. Kutscher. "A Survey of Physicians' Attitudes Toward Death and Bereavement," Journal of Thanatology. I (1971), pp. 91-100.

Pilsecker, Carl. "Help For the Dying," Social Work. 20 (May, 1975), pp. 190-194.

Popoff, David. "What Are Your Feelings About Death and Dying," Nursing. (August, 1975), pp. 68-64.

Prichard, E. (ed.), Social Work With the Dying Patient and the Family. New York: Columbia University Press, 1977.

Quint, J.C. Nurse and the Dying Patient. New York: MacMillan Co., 1967.

Rea, M. Priscilla, Shirley Greenspoon, and Bernard Splika. "Physicians and the Terminal Patient: Some Selected Attitudes and Behavior," Omega. 6(4) (1975), pp. 291-302.

Resinikoff, G. "Attitudes Toward Death: A Comparison of Nursing Students and Graduate Students," Nursing Research. 20 (1971), pp. 503-508.

Ringle, Erwin. "The Problem of Death Repression in Medical Training," Dynamische Psychiatrie. 8 (1975), pp. 143-158.

Schreibaum, D. "Approaches and Developments in the Study of Attitudes to Death," Israel Annals of Psychiatry and Related Disciplines. 13 (September, 1975), pp. 259-269.

Schulz, R. and D. Aderman. "How Medical Staff Copes With Dying Patients : A Critical Review," Omega. 7 (1) (1976), pp. 11-21.

Shneidman, Edwin S. "You and Death," Psychology Today. (June 1971) pp. 43-45; 74-80.

Simos, B. "Grief Therapy to Facilitate Healthy Restitution," Social Case Work. 58(June, 1977), pp. 337-342.

Stratton, L. and M. Hammon. "Physicians"Attitudes on Death and Dying," research study presented in Social Work Research Class, Portland State University, School of Social Work, Winter, 1975. 
Templer, D. I. "The Relationship Between Verbalized and Non-Verbalized Death Anxiety," Journal of Genetic Psychology. 119 (1971), pp. 211-214.

Travis, T. A., R. Noyes, and D.R. Brightwe11. International Journal of Psychiatry and Medicine. 5 (1974), pp. 17-26.

Weisman, Avery. The Realization of Death. New York: Aronson, 1974.

Yeaworth, R., F. Kapp, and C. Winget. "Attitudes Toward the Dying Patient," Nursing Research. 23 (Jan.-Feb., 1974), pp. 20-24. 
APPENDIX I

PILOT STUDY QUESTIONNAIRE 
DEATH AND DYING QUESTIONNAIRE EOR MEDICAL SOCIAL WORKERS

\section{Age}

2. Sex

3. Specific area of medical social work practice at hospital where you now work:

Pediatrics General Medicine Oncology Other

Psychiatry
Surgery (please list) Oncology

(check more than one if you are working in multiple areas)

4. How long have you been working in this/these particular area/areas? 非 months

5. How many medical social work positions have you held since the completion of gour M.S.W.?

6. Number of years of practice in a medical setting since the completion of your M.S.W.?

7. What percent of your patient caseload are terminal/dying patients? (please circle one) $0-10-20-30-40-50-60-70-80-90-100$

8. How many terminal patients have you had the opportunity to work with in the last year?

9. In your employment as a medical social worker, how many deaths have you actually been present at?

10. Durfng your social work education (M.S.W. program) did you take part in any course work, seminars, or specific training related to dealing with death, the terminal/ dying patient, and his or her family?

Yes

No

No Response

11. Would you please list or describe any specific training, academic or experiental, you have had related to the terminal/dying patient, and his or her family.

2. Would you please circle a number. which most adequately describes your feelings regarding the following statement.

"The skills I acquired, and the training I received in my M.S.W. program adequately prepared me for working with terminal/dying patients and their families"

Strongly agree

12

3

4

Strongly disagree

(if you disagree please state why) 
13. Do you feel as a social worker working in a medical setting that any special skills or training are needed to work with dying/terminal patients and their families?

Yes_ No___ Possibly____ No Response

14. Would you please list or describe what you feel are the essential skills needed to deal with the terminal/dying patient and his or her family.

15. What do you feel is the most important thing you can offer a terminal/dying patient as a medical social worker?

16. How important do you fejel it is for the family to be present at the time of the patients death?

Very Important

Moderately Important

Undecided

Not Important

17. Whose responsibility do you feel it is to tell the patient that he is dying, or has a terminal disease?

Chaplain___ Nurse____ Physician___ Family___ Social Worker

Other

(please describe)

18. What percent of your employment time do you actually spend working with terminal/dying patients and their families on a direct service, or ltol bas is?

$0-10-20-30-40-50-60-70-80-90-100 \quad$ (please circle one)

19. Would you please circle a number which most adequately describes your feelings regarding the following statement.

"The patient should always be told or made aware of the fact that he has a terminal condition, or is in fact dying".

Strongly agree

2

3

4

Strongly disagree

(if you disagree please state why) 
20. Do you consider yourself: Not religious

Somewhat religious

Very religious No Response

21. Do you have any religious preference? Yes which preference) Prot Cath No (if yes please indicate

22. Do you believe in life after death? Yes Jewish Mormon Other

23. Do you have any fear of dying? Always No No Response Never

24. How often do you think of your own death? Once a day Once a week Once a month Once a year Never

25. If you had a terminal illness, or a limited time to live, would you want your physician to tell you:

Immediately_ Not tell you
Tell you over a period of time
Tell your family first

26. Have you made any future fumeral arrangements for yourself? Yes

No No Response

27. Do you feel by working in a medical setting where death and dying are encountered on a regular basis, that one becomes immune to thinking about, or more cognizant of their own finiteness?

Immune

More cognizant

Neither

Both

Other

(please describe)

28. In your opinion how competent is the primary patient care staff (physicians, nurses, social workers, and various medical therapist such as inhalation therapy, and nuclear medicine) in coping with the needs of the terminal/dying patient and his family, at the medical facility in which you now work?

Not competent at all 1

23

3

4

Very competent

29. Do you feel the medical facility in which you now work offers enough inservice training (within the hospital) for the primary patient care staff in the area of the terminal/dying patient, and his or her family?

Yes___ Yes with certain qualifications

No_ No with certain qualifications

(please list any qualifications you might have) 
30. On the below scale would you please rate the social work department in which you now work with respect to it offering enough internal training for staff social workers in the area of the terminal/dying patient, and his or her family.

offers none at all 1

2

3

Offers more than enough

(please circle one)

31. Please respond to the following statement:

"The services provided to dying/terminal patients and their families, at the medical facility in which I now work could be improved."

Strongly agree

Agree

Undecided

Disagree

Strongly disagree

32. Please respond to the following statement:

"The services provided to the dying/terminal patients and their families,at

the medical facility in which I now work should be improved."

Strongly agree______ Agree____ Undecided______ Disagree____ Strongly disagree

33. It has been said by several authoritiest that medical technology with all. of its sophisticated equipment and procedures has gotten in the way of allowing the patient to experience his death in a dignified way. Would you please give any conments you might have regarding this assumption.

34. Please list any books you have read recently relating to death, terminal/dying patients, and their families.

Comments regarding questionnaire-

* Hans O. Mauksch, Ph.D., The Organizational Context of Dying, contained in Kubler-Ross's book "Death, The Final Stage of Growth", Prentice-Hall, Inc., Englewood Cliffs, New Jersey.

John Langone, Vital Signs: The Way We Die in America, Little, Brown and Company, Boston. 
APPENDIX II

LETTERS SENT TO STUDY PARTICIPANTS 
4755 N.W. Columbia Avenue Portland, Oregon 97229

March 12, 1977

Dear Social Worker:

I would like to introduce myself. I am Lon Stratton, a second-year graduate student at Portland State University School of Social Work. As part of the research requirement for my degree, I am conducting a survey of all M.S.W.S currently employed in Portland hospitals regarding their attitudes toward death, terminal patients, and other related matters.

Since you have an M.S.W. and currently work in a Portland hospital, I would appreciate your cooperation in completing the attached questionnaire. Please return the questionnaire in the enclosed stamped envelope as soon as possible, since I must be in receipt of the data by. March 29, 1977.

For your information, all data acquired on this questionnaire will be considered confidential. Please do not put your name or place of employment on the questionnaire. Lastly, you will notice on the front page of the questionnaire, in the bottom lefthand corner, a pair of numbers. This is a numerical code to identify the questionnaires, and let me know which ones have been returned. Once the questionnaire is sent back this code will be clipped off, thereby making it impossible to further identify the respondent. A follow-up letter will be sent to those individuals who have not returned the questionnaires by March 29, 1977.

Thank you for your time.

Sincerely,

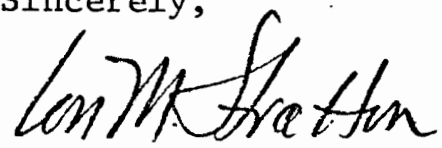

Lon M. Stratton 
4755 N.W. Columbia Avenue

Portland, Oregon 97229

Dear Social Worker:

Some time ago I sent you a questionnaire related to medical social workers' attitudes toward death and related matters. The response to this study has been excellent. However, for some reason I have not received your questionnaire. Enclosed you will find a questionnaire along with a stamped, return addressed envelope. I would greatly appreciate it. if you would please complete this second questionnaire and return it to me as soon as possible.

Thank you for all your help.

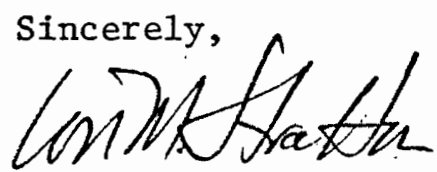

Lon M. Stratton 
APPENDIX III

FINAL QUESTIONNAIRE 
QUESTIONNAIRE ON DEATH AND DYING FOR MEDICAL SOCIAL WORKERS

Section I Demographic Data and Background Experience Rëlated to this Practice Area:

1. Age

2. Sex

3. How many medical social work positions have you held since completion of your M.S.W.?

$1-2$ 3-4_5-6_ More than 6

4. Number of years of practice in a medical setting since completion of your M.S.W.?

Less than 1 $1-4+5-8$ $9-12$

More than 12

5. Specify the area or areas of medical social work practice at the hospital where you now work. (check more than one if working in multiple areas)

Pediatrics General Medicine Surgery

Psychiatry Administration Geriatrics

oncology other

(Please Iist)

6. How long have you been working in this/these particular area(s)? Number of months

7. What per cent of your patient caseload is terminal/dying patients?

$0--10--20--30--40--50--60--70-\cdots 80-\cdots-90--100$

$$
\text { (please circle one) }
$$

8. What per cent of your employment time do you actually spend working with terminaldying patients and their families on a direct service, or one to one basis?

$$
\begin{gathered}
0-10--20-30--40 \cdots-50--60-70--80--90--100 \\
\text { (please circle one) }
\end{gathered}
$$

9. How many terminal/dying patients have you had the opportunity to work with in the last year?

0 $1-4$ 5-8 9-12 More than 12 
10. In your employment as a medical social worker, how many deaths have you actually witnessed?

$0 \quad 1-4 \ldots 5-8 \quad 9-12 \quad$ More than 12

Section:II Educational and Training Data Related to Working with Terminal/Dying Patients:

11. During your social work education (M.S.W. program) did you take part in any course work, seminars, or specific training related to dealing with death, the terminal/dying patient, and his/her family?

Yes

No

12. Please circle the number which best represents your feelings regarding the following statement.

"The skills I acquired and the training I received in my M.S.W. program adequately prepared me for working with terminal/dying patients and their families."

Strongly Agree

23

$\frac{\text { Strongly Disagree }}{5}$

13. Since the completion of your M.S.W. have you been involved in any training, academic or experiential, related to working with terminal/dying patients and their families?

Yes

No

Section III Specific Practice Data Related to Working With Teminal/Dying Patients and Their Families:

14. Please circle the number which most adequately describes your feelings regarding the following statement.

"The patient should always be told or made aware of the fact that he/she has a terminal condition, or is in fact dying."

$\frac{\text { Strongly Agree }}{1}$

2

3

$\frac{\text { Strongly Disagree }}{5}$

15. Whose responsibility do you feel it is to tell the patient that he is dying or has a terminal condition?

\begin{tabular}{lll} 
Chaplain_ Nurse_ & Family_ Physician \\
Social Worker & Other___ (Describe) \\
\hline
\end{tabular}


16. How important do you feel it is for the family to be present at the time of the patient's death?

Very important

Moderately important

Not important

Undecided

17. Do you feel a social worker practicing in a medical setting needs any special skills or training to deal with dying/terminal patients and their families?

Yes_ No_ No___ No Response

18. : What do you feel is the most important thing you can offer a terminal/dying patient as a medical social worker?

19. Please list or describe what you feel are the essential skills needed to deal with the terminal/dying patient and his/her family.

20. Which would you rather work with?

The terminal patient

The family of the terminal patient

It makes no difference

21. By continually working in a medical setting where death and terminal patients are encountered on a regular basis, one can become insensitive to the needs of the dying person, and his/her family?

$\frac{\text { Strongly Agree }}{1}$

2

$$
\text { (please circle one) }
$$

\section{$\frac{\text { Strongly Disagree }}{5}$}

Section IV Personal Data Related to Death and Dying:

22. Do you consider yourself:

Not religious

Somewhat religious

Very religious

No response 
23. Do you beliave in life after death?

Pes__ No___ No response

24. Do you have any fear of dying?

Always__ Sometimes___ Very seldom___ Never

25. How often do you think of your own death?

Once a day.

Once a week

Once a month

Once a year

Never

26. If you had a terminal illness or a limited time to live would you want your physician to tell you?

Immediately _ Not tell you Tell your family first

Tell you over a period of time

27. Have gou made any Euture funeral arrangements for your self?

Yes_ No___ No response

\section{Section V Data Related to Present Place of Employment}

28. In your opinion, how competent is the primary patient care staff (physicians, nurses, social workers) at your place of employment in coping with the needs of the terminal/dying patient and his family?

Very Incompetent

$$
2 \text { (please circle one) }
$$

4

$\frac{\text { Very Competent }}{5}$

29. Do you feel the medical facility in which you now work offers enough inservice training (within the hospital) for the primary patient care staff in the area of the terminal/dying patient and his/her family?

Yes

No

30. On the scale below, rate the social work department in which you now work with respect to its offering enough internal training for staff social workers in the area of the teminal/dying patient and related matters.

$\frac{\text { Offers none at al1 }}{1}$ 2

3

(please circle one)

$\frac{\text { Offers more than enough }}{5}$ 
31. Please respond to the following statement:

"The services provided to the dying/terminal patients and their families at the medical facility in which I now work could be improved."

$\frac{\text { Strongly Agree }}{1}$

2

3

$\frac{\text { Strongly Disagree }}{5}$

(please.circle one)

32. Please respond to the following statement:

"The services provided to the dying patient by the social work deparement in which I now work could be improved."

$\frac{\text { Strongly Agree }}{1}$

2

3

(please circle one)

$\frac{\text { Strongly Disagree }}{5}$

33. According to several authorities, * medical technology with all of its sophisticated equipment and procedures, has gotten in the way of allowing the patient to experience his death in a dignified way. Do you agree or disagree with this statement and why?

* Hans 0. Mauksch, Ph.D., The Organizational Context of Dying, contained in Kubler-Ross, "Death, The Final Stage of Growth," Prentice-Hall, Inc., Englewood Cliffs, New Jersey.

John Langone, Vital Signs: The Way we Die In America, Little, Brown and Company, Boston.

Questionnaire designed by Lon M. Stratton, Graduate Student, Portland State University School of

Social Work, March, 1977 